\title{
The effect of divalent and trivalent cations on aggregation and surface hydrophobicity of selected microorganism
}

\author{
M. Anwar Alias ${ }^{1}$, Khalida Muda ${ }^{\dagger}$, Augustine Chioma Affam², Azmi Aris ${ }^{3}$, Normala Hashim ${ }^{1}$ \\ ${ }^{1}$ Faculty of Civil Engineering, Universiti Teknologi Malaysia, Johor Bahru 81310, Malaysia \\ ${ }^{2}$ Department of Civil Engineering, School of Engineering and Technology, University College of Technology Sarawak, Persiaran Brooke, Sibu 96000, \\ Sarawak, Malaysia \\ ${ }^{3}$ Centre for Environmental Sustainability and Water Security (IPASA), Universiti Teknologi Malaysia, Johor Bahru 81310, Malaysia
}

\begin{abstract}
This study investigated the effect of various cations $\left(\mathrm{Ca}^{2+}, \mathrm{Mg}^{2+}, \mathrm{Al}^{3+}, \mathrm{Mn}^{2+}, \mathrm{Zn}^{2+}\right)$ on the autoaggregation (AAg) and surface hydrophobicity $(\mathrm{SHb})$ of three different bacteria (Brevibacillus panacihumi strain (ZB1), Lysinibacillus fusiformis strain (ZB2) and Enterococcus faecalis strain (ZL)) using a 2-level factorial design. The AAg ratio was measured from the changes in the absorbance of the media. Results show that ZB2 had maximum AAg for the three bacteria investigated. A microscopic clustering of cells was observed when $\mathrm{Ca}^{2+}$ was added to ZB2. The AAg was in the range of $62 \%, 58 \%$ and $34 \%$ for $\mathrm{ZB} 2, \mathrm{ZB} 1$ and $\mathrm{ZL}$, respectively and correlated to the $\mathrm{SHb}$. The aggregation and $\mathrm{SHb}$ of the microbial cells increased with increasing ionic strength due to the repulsive steric or overlap forces between the polymer covered surfaces. Ca ${ }^{2+} \mathrm{demonstrated}$ a more significant effect on aggregation and $\mathrm{SHb}$ of microbial cells due to an attractive binding force.
\end{abstract}

Keywords: Aggregation, Biogranules, Cations, Surface hydrophobicity

\section{Introduction}

Granules are formed by the interaction of microbial cells of different or similar strains through basic mechanism of autoaggregation (AAg) or coaggregation. AAg refers to the physical cell-to-cell interaction between genetically identical cells, whereas coaggregation refers to the interaction between genetically distinct bacterial cells. Microbial aggregation is a part of initial cell interaction which results in granule formation. Several factors such as type of seed sludge, type and concentration of substrate, presence of extracellular polymeric substrate (EPS), composition of the media, $\mathrm{pH}$, temperature and operational set-up of the reactor can affect the initial cell interactions. Additionally, surface hydrophobicity $(\mathrm{SHb})$ can also influence granule formation. Cell aggregation and $\mathrm{SHb}$ reportedly have a good correlation to the adhesion capacity of bacteria [1-3]. The factors that influence the adhesion ability of microbials cells have been widely investigated and could be measured through microbial aggregation and SHb [2, 4-10].

Granular sludge formed by cell immobilization consist of biofilm, entrapped microorganisms and microbial aggregates [11]. However, it differs from biofilm formation due to the absence of carrier materials [5, 12-15]. EPS is one of the biofilm components found in granular sludge [8, 16-17]. EPS can cause cell SHb and act as a driving force during biogranulation [5, 8-9, 18-19]. Many studies have reported that EPS and SHb are correlated. They facilitate the aggregation of bacteria and maintenance of the granular structure [8, 18, 20-21]. Several efforts have been made to enhance granulation with additives and change the start up or operating conditions either in aerobic or anaerobic systems [12]. Some of the notable additives are cations [22-26] and synthetic polymers [27-29]. Cations can facilitate the bridging of the negatively charged groups on the cell surface with the secreted EPS [23, 30-31]. This enables the initial cell interaction stage of granulation process. Nomura et al. 2009 reported that the aggregation of washed cells (Lactococcus lactis JCM 5805) slightly increased at high concentration of cations. In contrast, the aggregation of microbial cell in unwashed cell decreased with increasing cationic strength. Additionally, when EPS was present in suspensions of unwashed cells, a low concentration of cations were found during the aggregation of the microbial cells due to an attractive bridging force. From the application viewpoint, this technology could be useful in flocculation of dispersed

Received May 19, 2016 Accepted October 17, 2016

${ }^{\dagger}$ Corresponding author

Email: khalida@utm.my

Tel: +60-13777-4774 mits unrestricted non-commercial use, distribution, and
medium, provided the original work is properly cited.

Copyright (C) 2017 Korean Society of Environmental Engineers 
sludge, and binding of negatively charged cells to promote the granulation process using cations $\left(\mathrm{Ca}^{2+}, \mathrm{Mg}^{2+}, \mathrm{Fe}^{2+}\right.$ and $\left.\mathrm{Fe}^{3+}\right)$. It is also applicable in bacterial adhesion in wastewater treatment [32].

Granular formation require a long development time depending on the experimental conditions and set-up. In some cases, granules are formed in weeks or months, but require sufficient time to grow and increase in size. Previous studies have reported that bacterial behavior or characteristic is independent of the changes in the environment [33-34].

The aim of this study was to investigate the reaction of a few selected bacteria to any change or modifications in its environment. The effect of various cations $\left(\mathrm{Ca}^{2+}, \mathrm{Mg}^{2+}, \mathrm{Al}^{3+}, \mathrm{Mn}^{2+}\right.$ and $\left.\mathrm{Zn}^{2+}\right)$ on microbial aggregation and $\mathrm{SHb}$ of three bacteria (Brevibacillus panacihumi strain (ZB1), Lysinibacillus fusiformis strain (ZB2) and Enterococcus faecalis strain (ZL)) were examined in order to improve the aerobic granulation start-up. Statistical experimental design was used to provide a quantitative understanding of the main interaction effects of the input variables and to develop the correlation between the input variables and responses.

\section{Materials and Methods}

\subsection{Wastewater Composition}

The modified synthetic wastewater used in this study is described elsewhere [35]. Glucose (0.5 g/L), ethanol (0.125 g/L), and sodium acetate $(0.5 \mathrm{~g} / \mathrm{L})$ were used as the mixed carbon sources. The trace elements used in this study were based on the composition recommended by Zhang et al. [24].

\subsection{Preparation of Bacterial Inoculum}

The microorganisms used in this study were ZB1, ZB2 and ZL. Each bacteria was grown overnight in nutrient broth. The cultures were agitated in a rotary shaker at room temperature until the exponential growth phase was reached.

\subsection{Reactor Set-up}

The experiment was performed using a $1 \mathrm{~L}$ schott bottle as reactor. Oxygen was supplied to the reactor at a fixed aeration rate of 2 $\mathrm{L} / \mathrm{min}$, in a manner similar to that of Sequential batch reactor (SBR) system in order to mimick the SBR granulation technique and process. The working volume of the experiment was $250 \mathrm{~mL}(10 \% \mathrm{v} / \mathrm{v}$ of inoculum was used). The bacteria was incubated until the stationary phase was attained, thereafter, analysis was carried out.

\subsection{Divalent and Trivalent Cation Solutions}

The effect of divalent and trivalent cations on microbial AAg and $\mathrm{SHb}$ of three bacteria were investigated using aluminum chloride $\left(\mathrm{AlCl}_{3}\right)$, calcium chloride $\left(\mathrm{CaCl}_{2}\right)$, magnesium sulfate $\left(\mathrm{MgSO}_{4}\right)$, manganese chloride $\left(\mathrm{MnCl}_{2}\right)$ and zinc chloride $\left(\mathrm{ZnCl}_{2}\right)$. A stock solution of $100 \mathrm{~g} / \mathrm{L}$ was prepared for each cation and the working concentrations were prepared daily by means of dilution. The experimental conditions for cationic concentration and $\mathrm{SHb}$ during the initial cell interaction of the biogranulation pocess was based on previous study [25, 31, 36-37]. All cation solutions were sterilized at $121^{\circ} \mathrm{C}$ for $5 \mathrm{~min}$ [36] as shown in Table 1 .
Table 1. Composition of Divalent/Trivalent Cation Solutions

\begin{tabular}{cc}
\hline Composition & Concentration(mg/L) \\
\hline $\mathrm{AlCl}_{3} \cdot 6 \mathrm{H}_{2} \mathrm{O}\left(\mathrm{Al}^{3+}\right)$ & 20 \\
$\mathrm{CaCl}_{2} \cdot 6 \mathrm{H}_{2} \mathrm{O}\left(\mathrm{Ca}^{2+}\right)$ & 100 \\
$\mathrm{MgSO}_{4} \cdot 7 \mathrm{H}_{2} \mathrm{O}\left(\mathrm{Mg}^{2+}\right)$ & 40 \\
$\mathrm{MnCl}_{2} \cdot 4 \mathrm{H}_{2} \mathrm{O}\left(\mathrm{Mn}^{2+}\right)$ & 10 \\
$\mathrm{ZnCl}_{2}\left(\mathrm{Zn}^{2+}\right)$ & 5 \\
\hline
\end{tabular}

\subsection{Aggregation Test}

Aggregation tests were conducted to represent the adhesion ability of bacteria under the influence of divalent and trivalent cations based on the procedure used by Chen et al. [1] and Rahman et al. [2]. Each culture was incubated in the bioreactor at an aeration rate of $2 \mathrm{~L} / \mathrm{min}$. From each sample, about $10 \mathrm{~mL}$ of the culture was taken from the bioreactor and centrifuged at a slow centrifugation speed of $650 \mathrm{~g}$ for $2 \mathrm{~min}$ as described by Malik et al. [38]. Turbidity measurement was used as an indcator of the optical density (OD) of each sample at the initial and final stationary phase of bacteria growth.

The aggregation ability was expressed as AAg percentage (AAg\%) and was calculated using Eq. (1):

$$
\mathrm{AAg} \%=\left[\left(\mathrm{A}_{0}-\mathrm{A}\right) / \mathrm{A}_{0}\right] \times 100
$$

Where

$\mathrm{AAg} \%$ is the percentage of aggregation,

$\mathrm{A}_{0}$ is the absorbance of cultured media at $0 \mathrm{~h}$,

$\mathrm{A}$ is the absorbance of cultured media after centrifugation

For the AAg\%, the culture can be classified into three groups: high coaggregation (HAg: > 70\% Ag), medium aggregation (MAg: 20-70\% Ag) and low aggregation (LAg: < 20\% Ag) cultures. A high aggregation index denotes a strong tendency of the cells to agglomerate into an aggregate [7].

\subsection{SHb Test}

The SHb of the bacterial strains were based on the microbial adhesion to hydrocarbon assay. The $\mathrm{SHb}$ of bacteria was determined according to the methods described by Rahman et al. [2] and was modified to suit the sample used in this study.

Each bacteria culture was incubated in the aerated bioreactor. $10 \mathrm{~mL}$ of each sample was taken from the glass bottle (bioreactor) after the growth of bacteria reached the stationary phase. The bacterial cells were harvested by centrifugation at 4,000 rpm for $10 \mathrm{~min}$. The pellets obtained were washed twice with $50 \mathrm{mM}$ of $\mathrm{K}_{2} \mathrm{HPO}_{4}$ ( $\mathrm{pH} \mathrm{7.0)}$ and then resuspended in the same buffer to obtain an absorbance of about 0.5 at $660 \mathrm{~nm}$. Five (5) $\mathrm{mL}$ of bacterial suspension was mixed with $1 \mathrm{~mL}$ of xylene $\left(\mathrm{C}_{6} \mathrm{H}_{4}\left(\mathrm{CH}_{3}\right)_{2}\right)$ by vortexing for $120 \mathrm{~s}$ and then allowed to stand for $1 \mathrm{~h}$ at room temperature. The absorbance of the bacterial suspension in the aqueous phase after mixing $(\mathrm{S})$ was compared to the absorbance taken at the initial stage of the experiment $\left(\mathrm{S}_{0}\right)$. Changes in absorbance due to the bacterial adhesion to the hydrocarbons was measured at $660 \mathrm{~nm}$ by using an OD Meter (DR5000 HACH Spectrophometer). All the samples were analysed in duplicates. $\mathrm{The} \mathrm{SHb}$ was expressed as SHb\% and calculated by Eq (2):

$$
\mathrm{SHb} \%=\left[\left(\mathrm{S}_{0}-\mathrm{S}\right) / \mathrm{S}_{0}\right] \times 100
$$


Where

$\mathrm{SHb} \%$ is the Percentage of $\mathrm{SHb}$,

$\mathrm{S}_{0}$ is the absorbance of sample before mixing with xylene,

$\mathrm{S}$ is the absorbance of sample after extraction with xylene.

\subsection{Experimental Procedure}

All three bacteria were cultured separately in nutrient broth until the OD was close to 1 . Thereafter, about $25 \mathrm{~mL}(10 \% \mathrm{v} / \mathrm{v})$ of the cultured sample was inoculated in a separate $250 \mathrm{~mL}$ Schott bottle containing synthetic wastewater. The inoculated synthetic sample was allowed to incubate under aerobic condition until it reached the stationary phase. The aggregation and $\mathrm{SHb}$ assay were then carried out. Instead of using physical shaking as commonly reported in previous aggregation test $[2,10,39-40]$, aeration was used to provide a close resemblance to the techniques used in typical granulation process. $10 \mathrm{~mL}$ of each sample was withdrawn after the stationary phase was reached for the aggregation and $\mathrm{SHb}$ tests. To determine the effect of $\mathrm{Ca}^{2+}, \mathrm{Mg}^{2+}$, $\mathrm{Al}^{3+}, \mathrm{Mn}^{2+}$ and $\mathrm{Zn}^{2+}$ on aggregation and $\mathrm{SHb}$ of $\mathrm{ZL}, \mathrm{ZB} 1$ and $\mathrm{ZB} 2$ cultures, an experimental design was employed using Minitab® (Version 16.3.2). This approach showed the effect of each factor or input variable separately (termed as the main effect) and the effect of the interaction between the variables (termed as the interaction effect) on the responses (i.e., aggregation and $\mathrm{SHb}$ ). Thus, the outcome was quantitatively determined. The experimental design followed a 2-level factorial design (coded as -1 and +1 ) comprising of 64 runs. The $\mathrm{Ca}^{2+}, \mathrm{Mg}^{2+}, \mathrm{Al}^{3+}, \mathrm{Mn}^{2+}$ and $\mathrm{Zn}^{2+}$ range of values used in the experiments are shown in Table 2. The responses were measured as percentage aggregation (\%Ag) and percentage $\mathrm{SHb}(\% \mathrm{SHb})$.

Table 2. Variables and Their Values Used in the Experiment

\begin{tabular}{cccc}
\hline Composition & Unit & Low value (-1) & High value (+1) \\
\hline $\mathrm{A}: \mathrm{Ca}^{2+}$ & $\mathrm{mg} / \mathrm{L}$ & 0 & 100 \\
$\mathrm{~B}: \mathrm{Mg}^{2+}$ & $\mathrm{mg} / \mathrm{L}$ & 0 & 40 \\
$\mathrm{C}: \mathrm{Al}^{3+}$ & $\mathrm{mg} / \mathrm{L}$ & 0 & 20 \\
$\mathrm{D}: \mathrm{Mn}^{2+}$ & $\mathrm{mg} / \mathrm{L}$ & 0 & 10 \\
$\mathrm{E}: \mathrm{Zn}^{2+}$ & $\mathrm{mg} / \mathrm{L}$ & 0 & 5 \\
\hline
\end{tabular}

\section{Results and Discussion}

\subsection{AAg and SHb of ZL, ZB1 and ZB2 Strains in Synthetic Wastewater}

ZL, ZB1 and ZB2 were obtained from the decolourising bacteria isolated from textile wastewater and palm oil mill effluent [41-43].

3.1.1. Growth profile of ZL, ZB1 and ZB2 in synthetic wastewater Each bacteria was grown in synthetic wastewater with the addition of $10 \%(\mathrm{v} / \mathrm{v})$ nutrient broth under aerobic condition for a $24 \mathrm{~h}$ period. Individual bacterial growth was measured using spectrophotometer at a wavelength of $600 \mathrm{~nm}$. The growth profiles were determined by plotting the value of $\mathrm{OD}_{600}$ vs time. The growth profile of the various bacteria (ZL, ZB1 and ZB2) were obtained as shown in Fig. 1. The bacteria reached the stationary phase in $12 \mathrm{~h}$.

The AAg and SHb of the strains ZB1, ZB2 and ZL are shown in Table 3. These bacteria can be classified under the medium rank bacteria aggregation.

The plot of the measured AAg\% vs the $\mathrm{SHb} \%$ of the various strains indicates the extent of microbial adhesion to hydrocarbons. Correlation between AAg and SHb for each strain (ZB1, ZB2 and ZL)

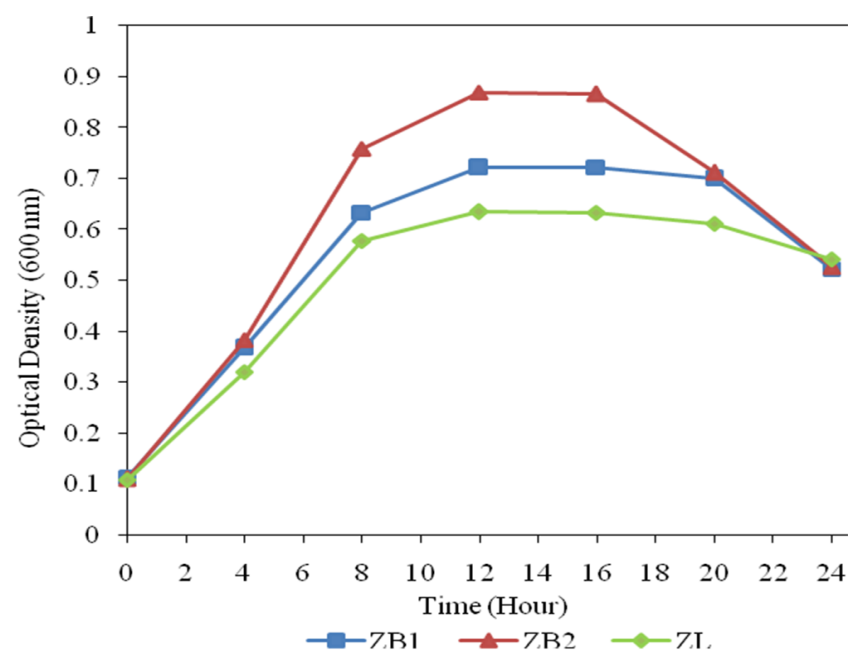

Fig. 1. Growth profile of the various bacteria in synthetic wastewater.

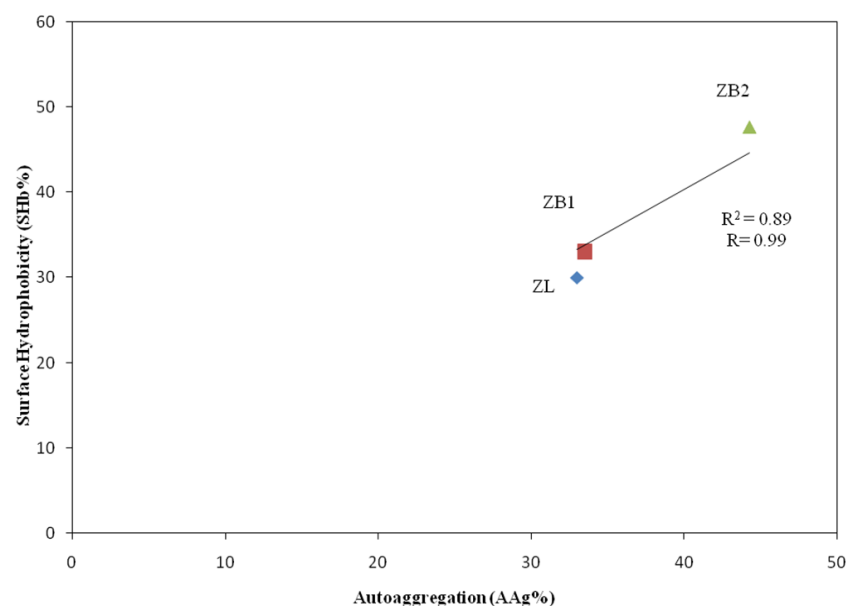

Fig. 2. Correlation between the two response variables ( $\mathrm{AAg} \%$ and $\mathrm{SHb} \%)$.

Table 3. AAg Ability and Shb of Bacterial Strains Used in the Present Study

\begin{tabular}{ccccc}
\hline Species & Strains & AAg (\%) & AAg Rank & SHb (\%) \\
\hline Enterococcus faecalis & ZL & $30.0 \pm 0.04$ & Medium & $33.0 \pm 0.40$ \\
Brevibacillus panacihumi & ZB1 & $33.0 \pm 0.01$ & Medium & $33.5 \pm 3.40$ \\
Lysinibacillus fusiformis & ZB2 & $47.7 \pm 3.03$ & Medium & $44.3 \pm 10.20$ \\
\hline
\end{tabular}

AAg: Autoaggregation; SHb: Surface hydrophobicity; AAg rank: Autoaggregation percentages $>70 \%$ ranked as high, $20-70 \%$ ranked as medium, and $<20 \%$ ranked as low autoaggregation strains. 


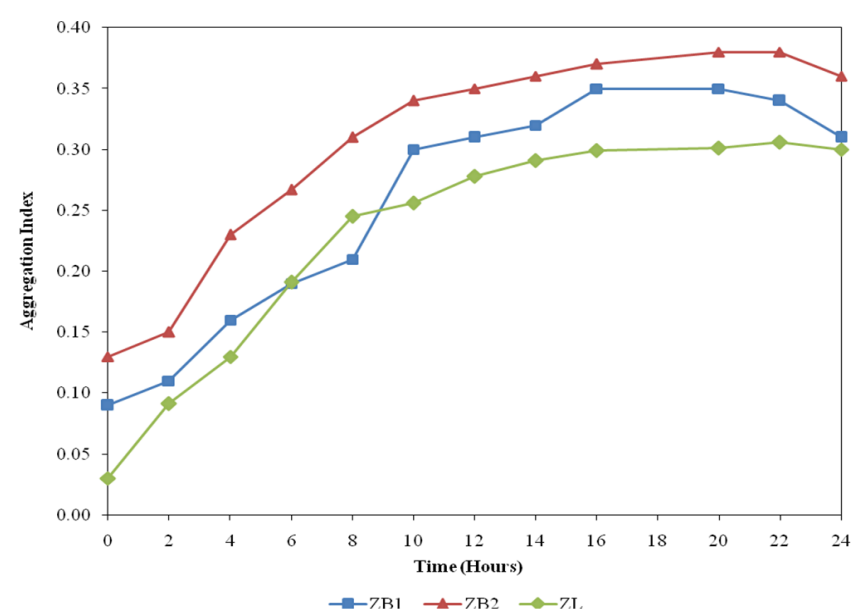

Fig. 3. Time course of AAg of ZB1, ZB2 and ZL in synthetic wastewater medium. was also calculated. A correlation $\left(\mathrm{r}^{2}\right)$ of 0.89 was obtained between $\mathrm{AAg}$ and $\mathrm{SHb}$ for the various strains. This result indicates that a good correlation exist between $\mathrm{AAg}$ and $\mathrm{SHb}$. Thus, $\mathrm{SHb}$ could be one of the determinants of AAg. The result obtained is in agreement with that of Rahman et al. [2].

Fig. 2 and Table 3 show the interdependece of $\mathrm{AAg} \%$ and $\mathrm{SHb} \%$ on each other. Thus, $\mathrm{SHb} \%$ can be referred to $\mathrm{AAg} \%$ for the various bacteria investigated. However, this hypothesis does not prove that it is applicable to other bacteria. $\mathrm{SHb}$ of bacteria can also be caused by the presence of EPS which notably causes adhesion between bacteria and floc [9]. Current understanding is based on a polymer-bridging model, where microbial aggregation is interpreted from the result of interactions of naturally produced EPS and microbial cells. EPS excreted by microbial cells play a key role in adsorbing and bridging cell surfaces. A direct correlation exist between EPS accumulation and microbial aggregation as well as bacteria $\mathrm{SHb}$.

Fig. 3 shows the changes in AAg\% with time for ZB1, ZB2 and ZL cultures under aerobic conditions. AAg\% in ZB1, ZB2 and ZL
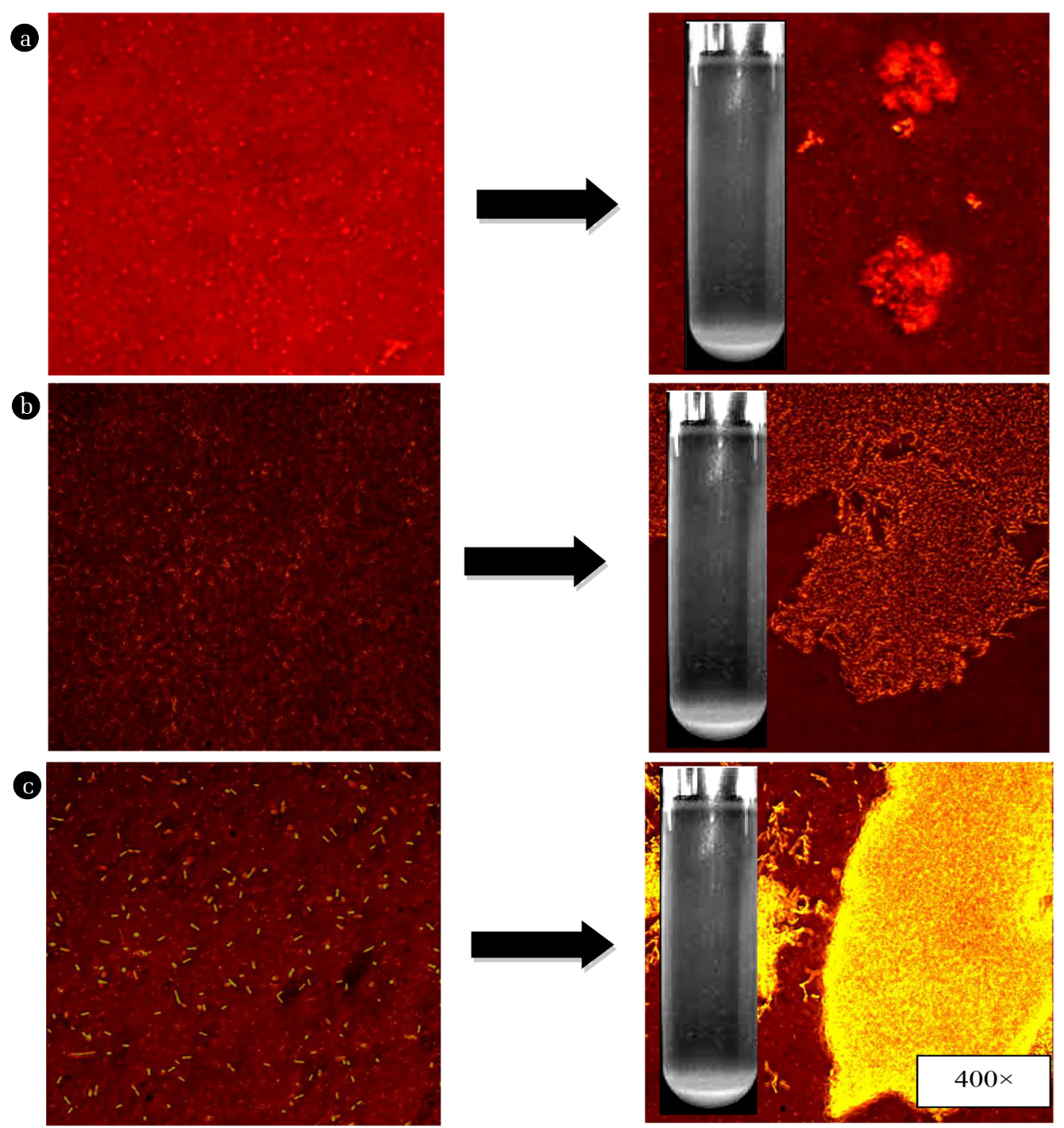

Fig. 4. Phase-contrast micrograph showing the morphology of (a) ZL, (b) ZB1 and (c) ZB2 after growth of $24 \mathrm{~h}$ (Mag. $400 \mathrm{x}$ ). 
bacteria showed an increasing trend with time at the exponential growth phase prior to the stationary growth phase. During the stationary growth phase, there was not much increase in the $\mathrm{AAg} \%$. A similar observation was made by Chen et al. [1] who noted that the autoaggregation of Aeromonas punctata strain T394 and Ochrobactrum anthropi strain WZR occurred in the activated sludge system.

Based on the categories [2], ZL, ZB1 and ZB2 were found in the medium AAg group. Although the various bacteria fall in the same rank, $\mathrm{AAg} \%$ for each bacteria was different. The sequence of AAg\% for the three bacteria were ZB2 > ZB1 > ZL. ZB2 also ranked highest during the incubation.

The AAg of the various bacteria could further be compared through their morphology as shown in Fig. 4. Fig. 4(a) - Fig. 4(c) represent the morphological structure of ZL, ZB1 and ZB2, respectively. The results show that the lowest $\mathrm{AAg} \%$ occurred in ZL due to small number of flocs whereas ZB1 had a cell aggregate formation with irregular-shaped flocs similar to ZB2. However, ZB2 appeared to have a dense clump of cells. Evidently, ZB2 had the most cell aggregate formation with irregular-shaped floc.

\subsection{Factorial Design Analysis}

3.2.1. Effect of cations on $\mathrm{AAg}$ and $\mathrm{SHb}$ of ZL, ZB1 and ZB2 bacteria Previous studies utilized physical shaking to generate shear force $[2,7,38]$. In order to mimic the real situation of the aerobic granulation process, physical shaking method was replaced with aeration in this study. This was to ensure consistent results comparable to conventional methods. Aeration was used to introduce the shear effect onto the microorganisms in the bioreactor. Furthermore, it helped to increase the contact angle of collision between microorganisms and cations which accelerated the aggregation process. The effect of the cations on these variables (AAg and $\mathrm{SHb}$ ) were presented by the responses produced. When the effect of one input variable affects the responses, there is an obvious interaction effect between the input variables.

The results from the factorial design were analyzed by the analysis of variance (ANOVA) to provide information on the estimated effects with their corresponding coefficients. ANOVA gave a summary of the significance of the main and interaction effects meas-

Table 4. Experimental Results of 2-Level Factorial Design Analysis (in coded levels)

\begin{tabular}{|c|c|c|c|c|c|c|c|c|c|c|c|}
\hline \multirow{2}{*}{ Run No. } & \multicolumn{5}{|c|}{ Factors } & \multicolumn{3}{|c|}{ AAg (\%) } & \multicolumn{3}{|c|}{ SHb (\%) } \\
\hline & $\mathrm{Ca}^{2+}$ & $\mathrm{Mg}^{2+}$ & $\mathrm{Al}^{3+}$ & $\mathrm{Mn}^{2+}$ & $\mathrm{Zn}^{2+}$ & ZL & ZB1 & ZB2 & ZL & ZB1 & ZB2 \\
\hline 1 & -1 & -1 & -1 & -1 & -1 & 35.6 & 38.5 & 33.9 & 25.7 & 35.9 & 46.3 \\
\hline 2 & +1 & -1 & -1 & -1 & -1 & 34.6 & 56.5 & 65.7 & 19.6 & 47.4 & 59.5 \\
\hline 3 & -1 & +1 & -1 & -1 & -1 & 17.3 & 39.3 & 45.7 & 24.9 & 43.0 & 37.8 \\
\hline 4 & +1 & +1 & -1 & -1 & -1 & 24.1 & 55.0 & 31.1 & 28.7 & 30.2 & 70.2 \\
\hline 5 & -1 & -1 & +1 & -1 & -1 & 19.3 & 53.7 & 12.7 & 17.3 & 21.9 & 46.7 \\
\hline 6 & +1 & -1 & +1 & -1 & -1 & 25.7 & 59.8 & 51.7 & 19.0 & 32.5 & 69.3 \\
\hline 7 & -1 & +1 & +1 & -1 & -1 & 16.6 & 45.1 & 16.4 & 12.8 & 29.9 & 46.3 \\
\hline 8 & +1 & +1 & +1 & -1 & -1 & 35.0 & 51.7 & 28.7 & 34.2 & 39.0 & 70.3 \\
\hline 9 & -1 & -1 & -1 & +1 & -1 & 18.6 & 44.8 & 49.8 & 19.0 & 41.8 & 51.4 \\
\hline 10 & +1 & -1 & -1 & +1 & -1 & 32.6 & 50.1 & 32.6 & 23.6 & 32.2 & 58.3 \\
\hline 11 & -1 & +1 & -1 & +1 & -1 & 15.7 & 46.2 & 28.3 & 17.9 & 38.4 & 43.8 \\
\hline 12 & +1 & +1 & -1 & +1 & -1 & 34.7 & 53.6 & 44.5 & 26.6 & 31.9 & 46.3 \\
\hline 13 & -1 & -1 & +1 & +1 & -1 & 22.3 & 42.9 & 49.1 & 5.3 & 39.1 & 45.4 \\
\hline 15 & -1 & +1 & +1 & +1 & -1 & 22.7 & 30.3 & 39.5 & 19.4 & 18.6 & 50.1 \\
\hline 16 & +1 & +1 & +1 & +1 & -1 & 31.9 & 62.9 & 63.7 & 28.7 & 45.5 & 72.9 \\
\hline 17 & -1 & -1 & -1 & -1 & +1 & 16.9 & 47.4 & 59.1 & 9.3 & 31.1 & 39.1 \\
\hline 18 & +1 & -1 & -1 & -1 & +1 & 32.1 & 51.7 & 58.8 & 27.5 & 41.6 & 58.8 \\
\hline 19 & -1 & +1 & -1 & -1 & +1 & 11.2 & 47.2 & 47.1 & 26.7 & 18.4 & 42.7 \\
\hline 20 & +1 & +1 & -1 & -1 & +1 & 30.5 & 56.4 & 53.4 & 11.7 & 40.2 & 61.5 \\
\hline 21 & -1 & -1 & +1 & -1 & +1 & 18.0 & 47.0 & 45.9 & 14.6 & 31.3 & 44.5 \\
\hline 22 & +1 & -1 & +1 & -1 & +1 & 38.1 & 59.3 & 63.4 & 22.1 & 39.1 & 66.3 \\
\hline 23 & -1 & +1 & +1 & -1 & +1 & 15.9 & 33.1 & 37.9 & 12.4 & 25.2 & 59.0 \\
\hline 24 & +1 & +1 & +1 & -1 & +1 & 30.2 & 58.9 & 45.7 & 19.4 & 46.3 & 58.7 \\
\hline 25 & -1 & -1 & -1 & +1 & +1 & 10.9 & 22.3 & 60.1 & 8.1 & 37.3 & 26.6 \\
\hline 26 & +1 & -1 & -1 & +1 & +1 & 25.2 & 45.6 & 28.1 & 27.3 & 28.2 & 78.5 \\
\hline 27 & -1 & +1 & -1 & +1 & +1 & 20.6 & 39.4 & 27.3 & 12.1 & 16.0 & 52.9 \\
\hline 28 & +1 & +1 & -1 & +1 & +1 & 32.0 & 47.4 & 70.8 & 25.4 & 31.6 & 70.9 \\
\hline 29 & -1 & -1 & +1 & +1 & +1 & 21.2 & 61.2 & 63.0 & 11.1 & 30.3 & 67.2 \\
\hline 30 & +1 & -1 & +1 & +1 & +1 & 25.2 & 64.9 & 60.2 & 18.3 & 39.6 & 61.8 \\
\hline 31 & -1 & +1 & +1 & +1 & +1 & 15.8 & 45.8 & 59.8 & 16.9 & 24.7 & 60.2 \\
\hline
\end{tabular}


Table 4. (Cont'd) Experimental Results for 2-Level Factorial Design Analysis (in coded levels)

\begin{tabular}{|c|c|c|c|c|c|c|c|c|c|c|c|}
\hline \multirow{2}{*}{ Run No. } & \multicolumn{5}{|c|}{ Factors } & \multicolumn{3}{|c|}{ AAg (\%) } & \multicolumn{3}{|c|}{ SHb (\%) } \\
\hline & $\mathrm{Ca}^{2+}$ & $\mathrm{Mg}^{2+}$ & $\mathrm{Al}^{3+}$ & $\mathrm{Mn}^{2+}$ & $\mathrm{Zn}^{2+}$ & ZLL & ZB1 & ZB2 & ZLL & ZB1 & ZB2 \\
\hline 32 & +1 & +1 & +1 & +1 & +1 & 41.7 & 59.9 & 74.0 & 37.7 & 29.5 & 42.1 \\
\hline 33 & -1 & -1 & -1 & -1 & -1 & 29.6 & 33.4 & 54.6 & 33.4 & 34.7 & 42.8 \\
\hline 34 & +1 & -1 & -1 & -1 & -1 & 31.9 & 27.2 & 52.4 & 27.2 & 52.2 & 45.7 \\
\hline 35 & -1 & +1 & -1 & -1 & -1 & 16.4 & 19.6 & 42.3 & 19.6 & 40.9 & 34.3 \\
\hline 36 & +1 & +1 & -1 & -1 & -1 & 28.0 & 15.7 & 52.1 & 15.7 & 57.5 & 27.9 \\
\hline 37 & -1 & -1 & +1 & -1 & -1 & 13.1 & 20.0 & 21.5 & 20.0 & 55.7 & 27.9 \\
\hline 38 & +1 & -1 & +1 & -1 & -1 & 33.2 & 31.1 & 74.5 & 31.1 & 59.8 & 43.7 \\
\hline 39 & -1 & +1 & +1 & -1 & -1 & 13.7 & 17.1 & 30.6 & 17.1 & 39.1 & 24.4 \\
\hline 40 & +1 & +1 & +1 & -1 & -1 & 26.6 & 36.8 & 31.0 & 36.8 & 57.7 & 41.1 \\
\hline 41 & -1 & -1 & -1 & +1 & -1 & 17.9 & 13.7 & 63.9 & 13.7 & 36.6 & 35.1 \\
\hline 42 & +1 & -1 & -1 & +1 & -1 & 31.5 & 14.8 & 42.2 & 14.8 & 46.3 & 31.6 \\
\hline 43 & -1 & +1 & -1 & +1 & -1 & 19.4 & 20.6 & 38.8 & 20.6 & 41.3 & 35.7 \\
\hline 44 & +1 & +1 & -1 & +1 & -1 & 33.8 & 22.1 & 50.6 & 22.1 & 56.0 & 37.3 \\
\hline 45 & -1 & -1 & +1 & +1 & -1 & 13.9 & 6.9 & 50.1 & 6.9 & 30.0 & 42.5 \\
\hline 46 & +1 & -1 & +1 & +1 & -1 & 36.6 & 13.6 & 39.2 & 13.6 & 66.5 & 36.7 \\
\hline 47 & -1 & +1 & +1 & +1 & -1 & 25.6 & 21.8 & 68.1 & 21.8 & 33.5 & 23.2 \\
\hline 48 & +1 & +1 & +1 & +1 & -1 & 34.8 & 22.2 & 68.5 & 22.2 & 59.1 & 45.3 \\
\hline 49 & -1 & -1 & -1 & -1 & +1 & 15.2 & 6.3 & 35.4 & 6.3 & 41.0 & 21.9 \\
\hline 50 & +1 & -1 & -1 & -1 & +1 & 32.2 & 21.8 & 73.0 & 21.8 & 51.8 & 42.9 \\
\hline 51 & -1 & +1 & -1 & -1 & +1 & 16.8 & 18.9 & 74.7 & 18.9 & 54.8 & 27.3 \\
\hline 52 & +1 & +1 & -1 & -1 & +1 & 34.4 & 11.8 & 24.8 & 11.8 & 55.8 & 37.9 \\
\hline 53 & -1 & -1 & +1 & -1 & +1 & 13.4 & 10.4 & 45.7 & 10.4 & 37.1 & 36.3 \\
\hline 54 & +1 & -1 & +1 & -1 & +1 & 32.8 & 20.1 & 69.8 & 20.1 & 60.7 & 38.7 \\
\hline 55 & -1 & +1 & +1 & -1 & +1 & 14.7 & 19.6 & 57.0 & 19.6 & 41.6 & 27.7 \\
\hline 56 & +1 & +1 & +1 & -1 & +1 & 24.7 & 20.6 & 25.8 & 20.6 & 62.2 & 43.7 \\
\hline 57 & -1 & -1 & -1 & +1 & +1 & 16.8 & 6.7 & 72.2 & 6.7 & 21.9 & 39.7 \\
\hline 58 & +1 & -1 & -1 & +1 & +1 & 29.1 & 20.2 & 47.0 & 20.2 & 57.5 & 44.8 \\
\hline 59 & -1 & +1 & -1 & +1 & +1 & 18.2 & 19.7 & 29.3 & 19.7 & 37.7 & 21.0 \\
\hline 60 & +1 & +1 & -1 & +1 & +1 & 33.7 & 29.5 & 40.2 & 29.5 & 50.3 & 45.6 \\
\hline 61 & -1 & -1 & +1 & +1 & +1 & 29.3 & 19.6 & 49.4 & 19.6 & 64.1 & 32.5 \\
\hline 62 & +1 & -1 & +1 & +1 & +1 & 35.8 & 21.6 & 38.9 & 21.6 & 77.2 & 37.2 \\
\hline 63 & -1 & +1 & +1 & +1 & +1 & 20.9 & 21.5 & 45.2 & 21.5 & 51.0 & 36.6 \\
\hline 64 & +1 & +1 & +1 & +1 & +1 & 38.6 & 30.1 & 75.6 & 30.1 & 60.6 & 24.9 \\
\hline
\end{tabular}

ured by the $P$-value. The responses obtained were statistically evaluated at $90 \%$ confidence level $(P$-value $<0.1)$. Table 4 shows the experimental result of the factorial design of the study. Each of the independent variable was investigated at a high $(+1)$ and low (-1) level.

3.2.2. The main effect of cations on $A A g$ of $Z L, Z B 1$ and $Z B 2$ Table 5 shows the five main effects of cations on AAg for ZL, ZB1 and ZB2 (ANOVA summary).

Calcium cation $\left(\mathrm{Ca}^{2+}\right)$ showed a significant effect with $P$-values less than 0.10 in the ZL, ZB1 and ZB2 cultures. Thus, an increase of $\mathrm{Ca}^{2+}$ concentration increased the $\mathrm{AAg} \%$. It is well known that $\mathrm{Ca}^{2+}$ is an important cation for the aggregation process and can increase the bioflocculation of most bacteria [25, 31, 44]. Mckinney and Horwood [45] and Tezuka et al. [44] proposed the rule of divalent cationic bridging function (DCB theory) which involves the interaction between divalent cations and negatively charged functional group of the EPS. In most biogranulation development; $\mathrm{Ca}^{2+}$ promotes the formation of cell-to-cell bridging, improve aggregation and stabilization of the biopolymer, enhance bioflocculation and the overall granulation process [30, 44-46].

The effect of magnesium cation $\left(\mathrm{Mg}^{2+}\right)$ on the $\mathrm{AAg}$ was not significant in each of the experimented bacteria. This result is in contrast with that of $\mathrm{Li}$ et al. [47], which stated that $\mathrm{Mg}^{2+}$ had similar effect as $\mathrm{Ca}^{2+}$ on microbial aggregation which helps in the cell-to-cell bridging of microorganisms. Additionally, it has been reported that $\mathrm{Mg}^{2+}$ accelerated the formation of aerobic granules [23]. In this study, $\mathrm{Mg}^{2+}$ had a weak effect on the structure of granules and could not play a bridging and core-induced role. This may imply that magnesium enhanced the sludge granulation 
Table 5. The $P$-values of the Estimated Effects of Divalent and Trivalent Cations on ZL, ZB1 and ZB2 AAg\% after $24 \mathrm{~h}$ Aeration

\begin{tabular}{|c|c|c|c|c|c|c|}
\hline \multirow{2}{*}{ Factors } & \multicolumn{2}{|c|}{ ZL } & \multicolumn{2}{|c|}{ ZB1 } & \multicolumn{2}{|c|}{ ZB2 } \\
\hline & Estimated effect & AAg\% & Estimated effect & AAg\% & Estimated effect & AAg\% \\
\hline $\mathrm{Ca}^{2+}$ & 13.345 & 0.000 & 15.196 & 0.000 & 13.444 & 0.000 \\
\hline $\mathrm{Mg}^{2+}$ & -0.679 & 0.446 & -1.070 & 0.297 & 0.375 & 0.857 \\
\hline $\mathrm{Al}^{3+}$ & 0.597 & 0.503 & 6.921 & 0.000 & 3.891 & 0.069 \\
\hline $\mathrm{Mn}^{2+}$ & 1.843 & 0.000 & -0.932 & 0.363 & -1.185 & 0.571 \\
\hline $\mathrm{Zn}^{2+}$ & -0.938 & 0.478 & 1.540 & 0.137 & -1.497 & 0.475 \\
\hline
\end{tabular}

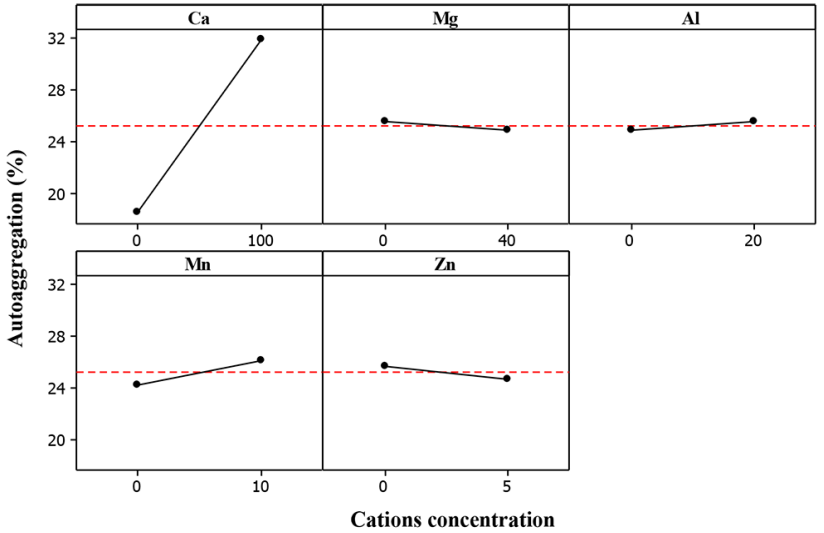

Fig. 5. Main effects plot for ZL AAg.

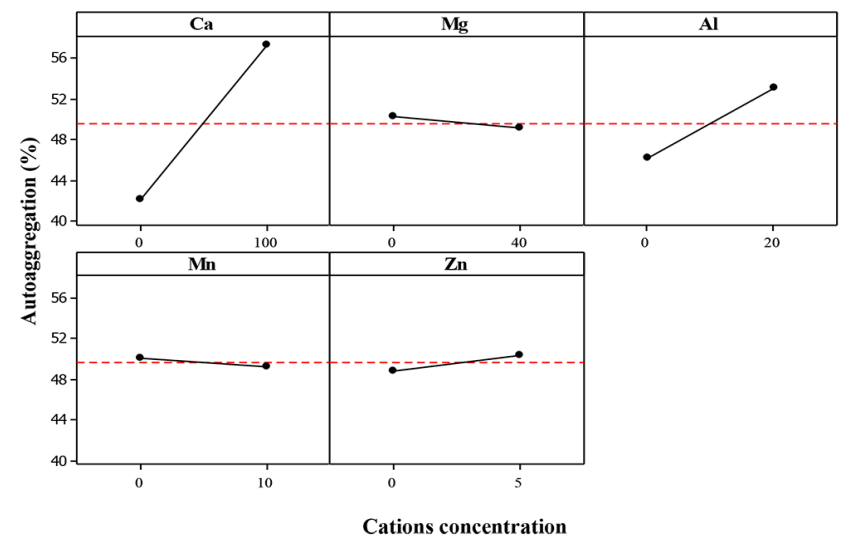

Fig. 6. Main effects plot for ZB1 AAg.

process through biochemical function. Although $\mathrm{Ca}^{2+}$ and $\mathrm{Mg}^{2+}$ cations have similar properties, their respective interaction with biopolymers or EPS differ [48]. The bound water content of sludge was not affected by $\mathrm{Mg}^{2+}$ addition, but was remarkably reduced with $\mathrm{Ca}^{2+}$ was addition [23]. Although the effect of $\mathrm{Mg}^{2+}$ on $\mathrm{AAg}$ in the various bacteria was not statistically significant, $\mathrm{Mg}^{2+}$ is an important trace element and a source of nutrient for metabolic enzymes during the growth of microorganisms [15, 23].

The effect of aluminum cation $\left(\mathrm{Al}^{3+}\right)$ on the AAg of ZB1 and ZB2 was significant, but was non-significant for ZL. The estimated main effects for ZB1 and ZB2 were 6.921 and 3.891, respectively. Fig. 5-7 show that the $\mathrm{AAg}$ of $\mathrm{ZB} 1$ and $\mathrm{ZB} 2$ increased with increasing $\mathrm{Al}^{3+}$. It has been reported that $\mathrm{Al}^{3+}$ can be used to reduce the required time for granule formation and increase aggregation rate [49].

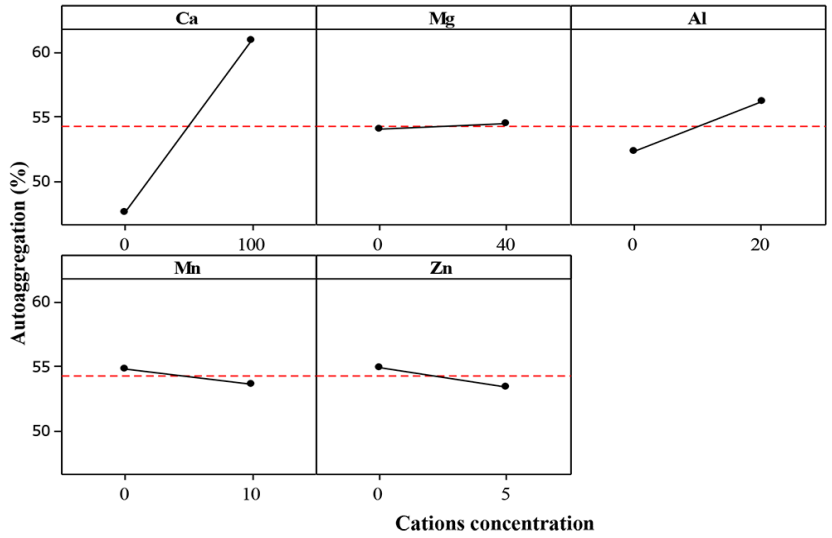

Fig. 7. Main effects plot for ZB2 AAg.

Unlike most metal cations, $\mathrm{Al}^{3+}$ is not required either in the macro or even micro-organisms as nutrients in biological growth [50].

The effect of manganese cation $\left(\mathrm{Mn}^{2+}\right)$ on the AAg of $\mathrm{ZL}$ culture was significant, but non-significant for ZB1 and ZB2 (Fig. 5). $\mathrm{Mn}^{2+}$ is among the essential nutrient required for microbial growth [50]. Huang et al. [51] utilized $\mathrm{Mn}^{2+}$ for augmentation during aerobic granule development. The authors found that $\mathrm{Mn}^{2+}$ augmentation could enhance the biogranulation process by stimulating the microbial diversity such as cell bridging and EPS secretion. Although there was a slight increase in $\mathrm{AAg} \%, \mathrm{Mn}^{2+}$ demonstrated the ability to cause microbial aggregation in the ZL culture. However the effect was largely different with that of $\mathrm{Ca}^{2+}$.

The effect of Zinc cation $\left(\mathrm{Zn}^{2+}\right)$ on the AAg of the various bacteria was not significant. This could be attributed to inappropriate concentration of $\mathrm{Zn}^{2+}$ which can inhibit microorganisms or bacteria activity. In addition, excess concentration of $\mathrm{Zn}^{2+}$ resulted to a decrease in EPS production and loosening of aggregated cells [52].

3.2.3. The main effect of cations on SHb of ZL, ZB1 and ZB2 The effect of calcium cations $\left(\mathrm{Ca}^{2+}\right)$ on the $\mathrm{SHb}$ for the three bacteria (ZL, ZB1 and ZB2) was significant with estimated main effect of 6.556, 6.882 and 5.515, respectively (Table 6).

From the statistical analysis, it could be explained that addition of $\mathrm{Ca}^{2+}$ caused an increase in Zl, ZB1 and ZB2 SHb\% (Fig. 8-10).

$\mathrm{Ca}^{2+}$ cations acted as a binder between EPS and cells by increasing the cell aggregation. At higher bacteria aggregation, higher hydrophobicity occurs which strengthens cell to cell interaction within the microbial structure [9, 35]. It serves as a protective mechanism for the cells against unfavorable environmental 
Table 6. The P-values of the Estimated Main Effects of Divalent and Trivalent Cations on ZL, ZB1 and ZB2 SHb\% after 24 h Aeration

\begin{tabular}{|c|c|c|c|c|c|c|}
\hline \multirow{2}{*}{ Factors } & \multicolumn{2}{|c|}{ ZL } & \multicolumn{2}{|c|}{ ZB1 } & \multicolumn{2}{|c|}{ ZB2 } \\
\hline & Estimated effect & SHb\% & Estimated effect & SHb\% & Estimated effect & $\mathrm{SHb} \%$ \\
\hline $\mathrm{Ca}^{2+}$ & 6.556 & 0.000 & 6.882 & 0.000 & 5.515 & 0.069 \\
\hline $\mathrm{Mg}^{2+}$ & 4.338 & 0.000 & -3.725 & 0.003 & -4.624 & 0.124 \\
\hline $\mathrm{Al}^{3+}$ & -0.126 & 0.906 & -0.920 & 0.429 & 0.812 & 0.783 \\
\hline $\mathrm{Mn}^{2+}$ & -1.387 & 0.201 & -0.958 & 0.410 & 5.042 & 0.095 \\
\hline $\mathrm{Zn}^{2+}$ & -2.206 & 0.046 & -2.058 & 0.082 & 7.262 & 0.019 \\
\hline
\end{tabular}

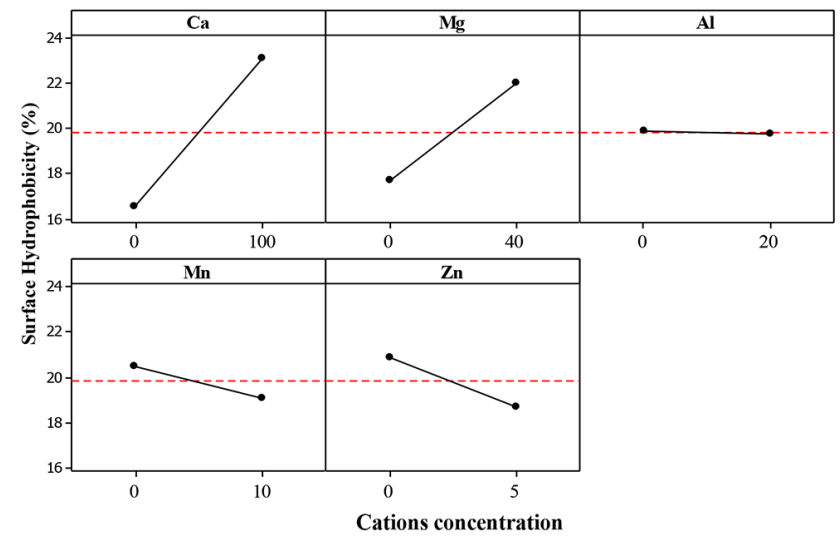

Fig. 8. Main effects plot for ZL SHb.

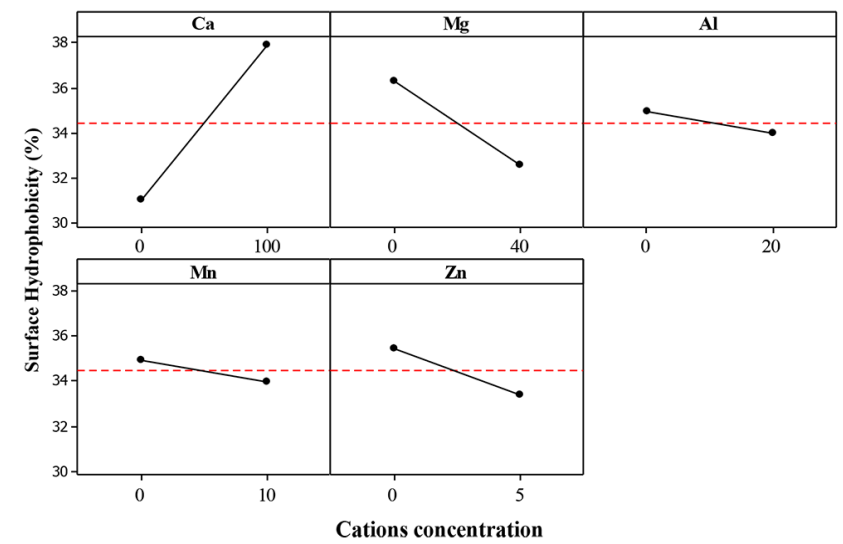

Fig. 9. Main effects plot for ZB1 SHb.

conditions. Higgins and Novak [53] reported that the addition of $\mathrm{Ca}^{2+}$ to activated sludge caused a decrease of the bound water content which increased aggregation.

It is well known that the presence of EPS can enhance cell $\mathrm{SHb}$ [18]. EPS is produced when the bacteria is under stress conditions. Although $\mathrm{Ca}^{2+}$ does not produce EPS, the increase in $\mathrm{Ca}^{2+}$ may create stress condition on bacteria. This could increase the production of the EPS due to the changing environmental conditions [54]. The three bacteria strains used in this study could have been exposed to stress condition due to the presence of excess $\mathrm{Ca}^{2+}$. This was evident by the production of EPS and the subsequent SHb occurrence. Fig. 10 shows that the bonding between EPS and the aggregate cells increased with increasing $\mathrm{Ca}^{2+}$ concentration, suggesting that $\mathrm{Ca}^{2+}$ may create a stronger bond.

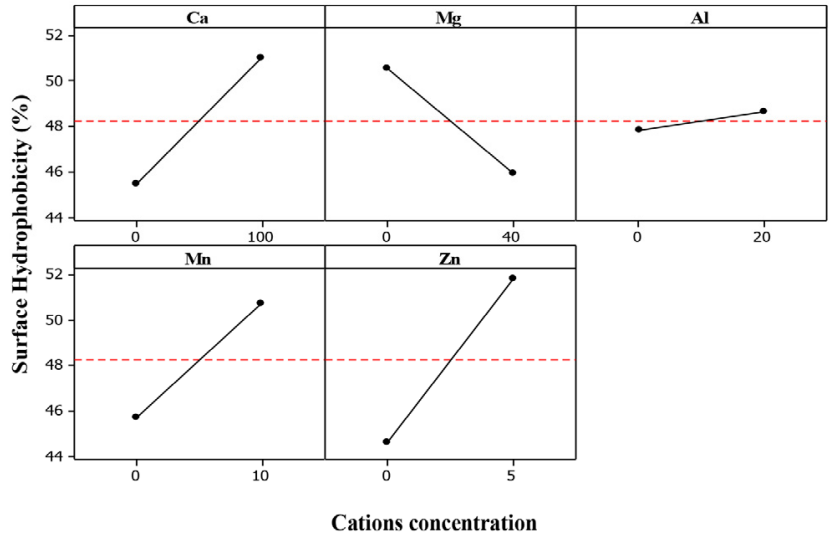

Fig. 10. Main effects plot for ZB2 SHb.

The result of the factorial design for the effect of calcium $\left(\mathrm{Ca}^{2+}\right)$ on $\mathrm{SHb}$ was significant for all three bacteria experimented. The cell- to-cell bridging with the negatively charged sites on the EPS and bacteria surfaces increased with increasing $\mathrm{Ca}^{2+}$ concentration $[51,55]$. Additionally, $\mathrm{Ca}^{2+}$ served as a cofactor or enzyme to induce the bacterial growth. Li et al. [48] reported that high EPS level was detected in anaerobic and aerobic granulation process in the presence of excess $\mathrm{Ca}^{2+}$ because the carbon utilization shifted towards EPS production. Increase in the cell-to-cell bridging between EPS and bacteria caused an increase in the SHb and the bacteria became more hydrophobic which facilitated adhesion or aggregation process [9]. The effect of $\mathrm{Ca}^{2+}$ had the same pattern with regards to the responses (AAg\% and $\mathrm{SHb} \%$ ) in the presence of EPS. It is well known that EPS can capably mediate both the cohesion and adhesion of cells and play a fundamental role in sustaining the structural integrity in the development of biofilm, anaerobic and aerobic granules [38, 56].

Table 6 shows that the effect of $\mathrm{Mg}^{2+}$ on the $\mathrm{SHb}$ of $\mathrm{ZL}$ and ZB1 was significant, but non-significant for ZB2. The estimated main effect for ZL and ZB1 were 4.338 and 3.725, respectively. From the statistical analysis, addition of $\mathrm{Mg}^{2+}$ did not increase the $\mathrm{SHb} \%$ of ZB2. Although the estimated effect of $\mathrm{Mg}^{2+}$ on $\mathrm{SHb}$ of $\mathrm{ZB} 1$ was negative, the effect was significant because it probably yielded a good interaction with other cations (Fig. 9). The $\mathrm{Mg}^{2+}$ cations promoted microbial aggregation and acted as a bridge for other bacteria surfaces and EPS. Additionally, the presence of $\mathrm{Mg}^{2+}$ produced higher amounts of EPS. However, further increase of $\mathrm{Mg}^{2+}$ did not yield an increase in the $\mathrm{SHb} \%$ of $\mathrm{ZB} 2$. This result is in agreement with that of Nguyen et al. [49]. It is also reported that the addition of $\mathrm{Mg}^{2+}$ to sludge had no effect on the bound water content [57]. 
The effect of $\mathrm{Al}^{3+}$ on the $\mathrm{SHb}$ of ZB2 was significant, indicating that the estimated main effect of $\mathrm{Al}^{3+}$ on $\mathrm{SHb}$ was positive. Thus, $\mathrm{AAg}$ of ZB2 increased with increasing $\mathrm{Al}^{3+}$ (Fig. 10). Park et al. [57] reported that the concentrations of soluble and colloidal biopolymer are low when $\mathrm{Al}^{3+}$ are present in activated sludge, but improves the sludge dewatering property. This indicates that $\mathrm{Al}^{3+}$ could reduce the bound water on the surface of aggregate cells. These results suggest that $\mathrm{Al}^{3+}$ could improve the $\mathrm{ZB} 2 \mathrm{SHb}$ properties by increasing the cell aggregate bond.

\subsubsection{The effect of cations on AAg for ZL, ZB1 and ZB2}

Significant 2-way interactions were observed between $\mathrm{Al}^{3+}$ and $\mathrm{Mn}^{2+}(\mathrm{Al} \times \mathrm{Mn}), \mathrm{Al}^{3+}$ and $\mathrm{Zn}^{2+}(\mathrm{Al} \times \mathrm{Zn}), \mathrm{Mg}^{2+}$ and $\mathrm{Mn}^{2+}(\mathrm{Mg}$ $\times \mathrm{Mn})$ and $\mathrm{Ca}^{2+}$ and $\mathrm{Zn}^{2+}(\mathrm{Ca} \times \mathrm{Zn})$. The interaction between $\mathrm{Al}^{3+}$ and $\mathrm{Mn}^{2+}$ was monitored at zero $\mathrm{Mn}^{2+}$ concentration. The AAg\% slightly decreased from $25 \%$ to $22 \%$ with increasing $\mathrm{Al}^{3+}$ concentration from $0-20 \mathrm{mg} / \mathrm{L}$. The effect of cations on AAg of ZL is presented in Table 7.
Fig.11 shows that the AAg increased in the range of $24-28 \%$ at a fixed $\mathrm{Mn}^{2+}$ and $\mathrm{Al}^{3+}$ concentrations of $10 \mathrm{mg} / \mathrm{L}$ and $20 \mathrm{mg} / \mathrm{L}$, respectively. The combined addition of $\mathrm{Al}^{3+}$ and $\mathrm{Zn}^{2+}$ to the $\mathrm{ZL}$ culture at concentrations of $0 \mathrm{mg} / \mathrm{L}$ and $20 \mathrm{mg} / \mathrm{L}$ caused a slight decrease of AAg from $26 \%$ o $22 \%$, but was in the range of $25 \%$ to $26 \%$ when $\mathrm{Zn}^{2+}$ concentration was reduced to $5 \mathrm{mg} / \mathrm{L}$. At $\mathrm{Al}^{3+}$ and $\mathrm{Zn}^{2+}$ concentrations of $20 \mathrm{mg} / \mathrm{L}$ and $5 \mathrm{mg} / \mathrm{L}$, AAg was about $26 \%$.

At a $\mathrm{Mn}^{2+}$ concentration of $10 \mathrm{mg} / \mathrm{L}$, the $\mathrm{AAg}$ of the ZL culture slightly decreased from $26 \%$ to $24 \%$. AAg further increased to $29 \%$ with the addition of $\mathrm{Mg}^{2+}$ upto a concentration of $40 \mathrm{mg} / \mathrm{L}$.

The AAg of the ZL culture decreased from $20 \%$ to $17 \%$ when $\mathrm{Zn}^{2+}$ concentration of $5 \mathrm{mg} / \mathrm{L}$ was added. However, the combined addition of $\mathrm{Ca}^{2+}$ and $\mathrm{Zn}^{2+}$ at a fixed concentrations of $100 \mathrm{mg} / \mathrm{L}$ and $5 \mathrm{mg} / \mathrm{L}$ caused an increase of AAg from $30 \%$ to $34 \%$ as shown in Fig. 11

The interaction between $\mathrm{Mg}^{2+}, \mathrm{Al}^{3+}$ and $\mathrm{Zn}^{2+}(\mathrm{Mg} \times \mathrm{Al} \times \mathrm{Zn})$ was the only significant 3-way interactions. In the 4-way interactions,

Table 7. The $P$-values of the Estimated Interaction Effects of Divalent and Trivalent Cations on ZL, ZB1 and ZB2 AAg\% after $24 \mathrm{~h} \mathrm{Aeration}$

\begin{tabular}{|c|c|c|c|c|c|c|}
\hline \multirow{2}{*}{ Factors } & \multicolumn{2}{|c|}{ ZL } & \multicolumn{2}{|c|}{ ZB1 } & \multicolumn{2}{|c|}{ ZB2 } \\
\hline & Estimated effect & AAg \% & Estimated effect & AAg \% & Estimated effect & AAg \% \\
\hline \multicolumn{7}{|c|}{ 2-way interaction } \\
\hline $\mathrm{Ca} \times \mathrm{Al}$ & 0.635 & 0.476 & 2.083 & 0.047 & -5.140 & 0.018 \\
\hline $\mathrm{Mg} \times \mathrm{Al}$ & 0.812 & 0.363 & -6.054 & 0.000 & -2.746 & 0.194 \\
\hline $\mathrm{Al} \times \mathrm{Mn}$ & 2.837 & 0.003 & 4.296 & 0.000 & 0.234 & 0.911 \\
\hline $\mathrm{Al} \times \mathrm{Zn}$ & 1.942 & 0.035 & 2.865 & 0.008 & 0.420 & 0.841 \\
\hline $\mathrm{Ca} \times \mathrm{Mg}$ & 1.228 & 0.173 & -0.266 & 0.794 & -2.553 & 0.226 \\
\hline $\mathrm{Ca} \times \mathrm{Mn}$ & 0.197 & 0.824 & 2.027 & 0.053 & -1.571 & 0.454 \\
\hline $\mathrm{Ca} \times \mathrm{Zn}$ & 1.671 & 0.067 & -0.960 & 0.349 & -1.882 & 0.370 \\
\hline $\mathrm{Mg} \times \mathrm{Mn}$ & 3.403 & 0.001 & -0.392 & 0.700 & -0.299 & 0.886 \\
\hline $\mathrm{Mg} \times \mathrm{Zn}$ & 1.164 & 0.196 & 0.965 & 0.609 & -0.176 & 0.933 \\
\hline $\mathrm{Mn} \times \mathrm{Zn}$ & 0.528 & 0.553 & 0.522 & 0.346 & 0.748 & 0.720 \\
\hline \multicolumn{7}{|c|}{ 3-way interaction } \\
\hline $\mathrm{Ca} \times \mathrm{Mg} \times \mathrm{Al}$ & -0.528 & 0.557 & 2.183 & 0.038 & -1.818 & 0.386 \\
\hline $\mathrm{Ca} \times \mathrm{Al} \times \mathrm{Mn}$ & -1.402 & 0.121 & 0.555 & 0.587 & -1.741 & 0.407 \\
\hline $\mathrm{Ca} \times \mathrm{Al} \times \mathrm{Zn}$ & -0.943 & 0.292 & -0.951 & 0.353 & -4.594 & 0.034 \\
\hline $\mathrm{Mg} \times \mathrm{Al} \times \mathrm{Mn}$ & -2.698 & 0.159 & -1.250 & 0.225 & 0.936 & 0.654 \\
\hline $\mathrm{Mg} \times \mathrm{Al} \times \mathrm{Zn}$ & -0.943 & 0.004 & -0.951 & 0.488 & -4.594 & 0.039 \\
\hline $\mathrm{Al} \times \mathrm{Mn} \times \mathrm{Zn}$ & -0.115 & 0.897 & 6.252 & 0.000 & 3.111 & 0.143 \\
\hline $\mathrm{Ca} \times \mathrm{Mg} \times \mathrm{Mn}$ & 0.501 & 0.573 & -1.371 & 0.184 & 1.137 & 0.587 \\
\hline $\mathrm{Ca} \times \mathrm{Mg} \times \mathrm{Zn}$ & 0.199 & 0.573 & -1.333 & 0.196 & -4.964 & 0.022 \\
\hline $\mathrm{Ca} \times \mathrm{Mn} \times \mathrm{Zn}$ & -1.783 & 0.823 & -1.241 & 0.228 & 2.346 & 0.266 \\
\hline $\mathrm{Mg} \times \mathrm{Mn} \times \mathrm{Zn}$ & -0.408 & 0.897 & -1.887 & 0.071 & -0.366 & 0.861 \\
\hline \multicolumn{7}{|c|}{ 4-way interaction } \\
\hline $\mathrm{Ca} \times \mathrm{Mg} \times \mathrm{Al} \times \mathrm{Mn}$ & 1.490 & 0.100 & 0.085 & 0.933 & 5.525 & 0.012 \\
\hline $\mathrm{Ca} \times \mathrm{Mg} \times \mathrm{Al} \times \mathrm{Zn}$ & 1.327 & 0.141 & 1.588 & 0.126 & 0.658 & 0.753 \\
\hline $\mathrm{Ca} \times \mathrm{Al} \times \mathrm{Mn} \times \mathrm{Zn}$ & 1.769 & 0.053 & -6.546 & 0.351 & -2.478 & 0.240 \\
\hline $\mathrm{Ca} \times \mathrm{Mg} \times \mathrm{Mn} \times \mathrm{Zn}$ & 2.237 & 0.016 & -0.956 & 0.000 & 0.712 & 0.733 \\
\hline $\mathrm{Mg} \times \mathrm{Al} \times \mathrm{Mn} \times \mathrm{Zn}$ & 1.029 & 0.251 & -1.679 & 0.106 & -2.48 & 0.242 \\
\hline \multicolumn{7}{|c|}{ 5-way interaction } \\
\hline $\mathrm{Ca} \times \mathrm{Mg} \times \mathrm{Al} \times \mathrm{Mn} \times \mathrm{Zn}$ & 1.789 & 0.051 & 1.790 & 0.086 & 1.654 & 0.430 \\
\hline
\end{tabular}

Significant Level $=90 \%(0.1)$ 


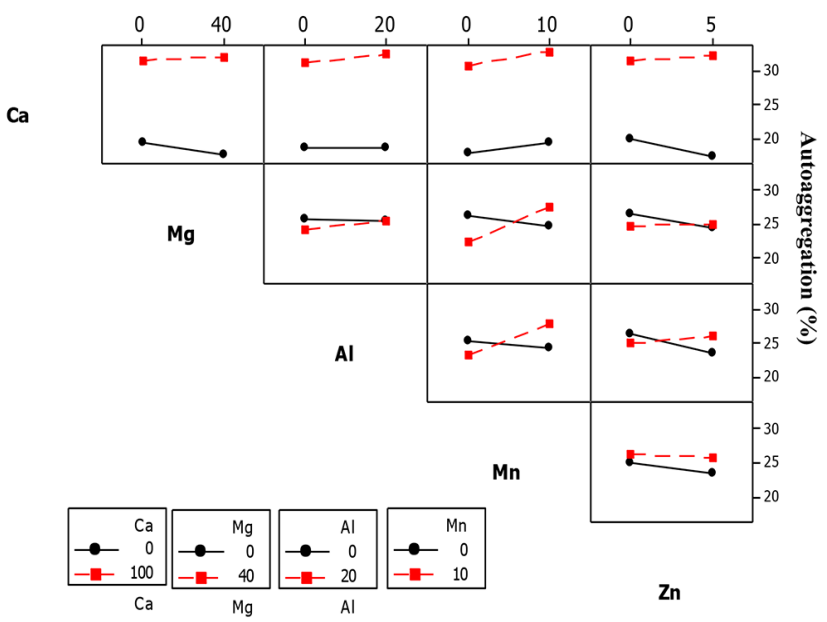

Fig. 11. Interaction plot of $\mathrm{AAg} \%$ of $\mathrm{ZL}$.

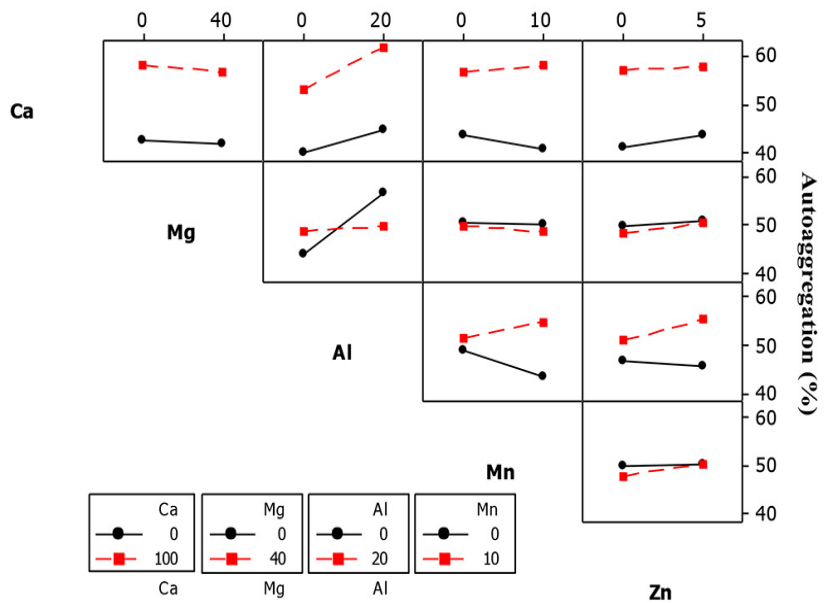

Fig. 12. Interaction plot for ZB1 AAg.

the three significant groups were $\mathrm{Ca}^{2+}, \mathrm{Mg}^{2+}, \mathrm{Al}^{3+}$ and $\mathrm{Mn}^{2+}\left(\mathrm{Ca}^{2+}\right.$ $\left.\times \mathrm{Mg}^{2+} \times \mathrm{Al}^{3+} \times \mathrm{Mn}^{2+}\right), \mathrm{Ca}^{2+}, \mathrm{Mg}^{2+}, \mathrm{Mn}^{2+}$ and $\mathrm{Zn}^{2+}(\mathrm{Ca} \times \mathrm{Mg}$ $\times \mathrm{Mn} \times \mathrm{Zn})$ and $\mathrm{Ca}^{2+}, \mathrm{Al}^{3+}, \mathrm{Mn}^{2+}$ and $\mathrm{Zn}^{2+}(\mathrm{Ca} \times \mathrm{Al} \times \mathrm{Mn}$ $\times \mathrm{Zn}$ ). In the 5-way interactions, $\mathrm{Ca} \times \mathrm{Mg} \times \mathrm{Al} \times \mathrm{Mn} \times \mathrm{Zn}$ were significant. The results of the factorial analysis for the individual and combined cationic effect on the AAg of the ZL culture varied inconsistently. The 2-way interaction effects between $\mathrm{Ca}^{2+}$ and $\mathrm{Al}^{3+}(\mathrm{Ca} \times \mathrm{Al}), \mathrm{Ca}^{2+}$ and $\mathrm{Mn}^{2+}(\mathrm{Ca} \times \mathrm{Mn}), \mathrm{Mg}^{2+}$ and $\mathrm{Al}^{3+}$ $(\mathrm{Mg} \times \mathrm{Al}), \mathrm{Al}^{3+}$ and $\mathrm{Mn}^{2+}(\mathrm{Al} \times \mathrm{Mn})$ and $\mathrm{Al}^{3+}$ and $\mathrm{Zn}^{2+}(\mathrm{Al}$ $\times \mathrm{Zn}$ ) were significant as shown in Fig. 12. The AAg of ZB1 increased from $39-43 \%$ at $\mathrm{Al}^{3+}$ concentration of $20 \mathrm{mg} / \mathrm{L}$. An interaction effect was observed when $\mathrm{Ca}^{2+}$ concentration of $100 \mathrm{mg} / \mathrm{L}$ was added to the ZB1 culture, resulting in an increase of AAg from $50-65 \%$ (Fig. 12). In contrast, the AAg of ZB1 culture decreased from $43-39 \%$ when exposed to $\mathrm{Mn}^{2+}$ concentration of $10 \mathrm{mg} / \mathrm{L}$, but increased from $55 \%$ to $58 \%$ when $\mathrm{Ca}^{2+}$ concentration of 100 $\mathrm{mg} / \mathrm{L}$ was added to the culture (Fig. 12).

The AAg of ZB1 culture also showed an increasing trend from $41 \%$ to $59 \%$ when exposed to $\mathrm{Al}^{3+}$ concentration of $20 \mathrm{mg} / \mathrm{L}$ but slightly increased from $49 \%$ to $50 \%$ when $\mathrm{Mg}^{2+}$ concentration of $40 \mathrm{mg} / \mathrm{L}$ was added to the culture (Fig. 12). However, AAg

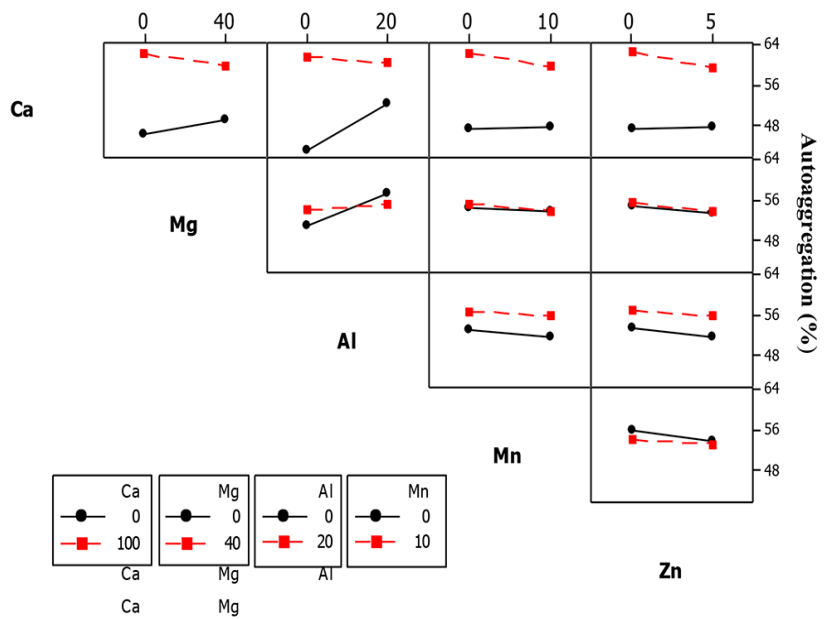

Fig. 13. Interaction plot for ZB2 AAg.

of ZB1 culture decreased from $49 \%$ to $43 \%$ when exposed to $\mathrm{Mn}^{2+}$ concentration of $10 \mathrm{mg} / \mathrm{L}$, but increased in the range of $50-55 \%$ when $\mathrm{Al}^{3+}$ concentration of $20 \mathrm{mg} / \mathrm{L}$ was added to the culture.

The AAg of ZB1 culture remained almost constant in the range of $46-45 \%$ when exposed to $\mathrm{Al}^{3+}$ concentration of $5 \mathrm{mg} / \mathrm{L}$, but increased in the range of $50-55 \%$ when exposed to $\mathrm{Al}^{3+}$ and $\mathrm{Zn}^{2+}$ concentrations of $20 \mathrm{mg} / \mathrm{L}$ and $5 \mathrm{mg} / \mathrm{L}$, respectively. In the 3-way interactions, the five significant effects observed were $\mathrm{Ca}^{2+}, \mathrm{Mg}^{2+}$ and $\mathrm{Al}^{3+}(\mathrm{Ca} \times$ $\mathrm{Mg} \times \mathrm{Al}), \mathrm{Ca}^{2+}, \mathrm{Mg}^{2+}$ and $\mathrm{Mn}^{2+}(\mathrm{Ca} \times \mathrm{Mg} \times \mathrm{Mn}), \mathrm{Ca}^{2+}, \mathrm{Mg}^{2+}$ and $\mathrm{Zn}^{2+}(\mathrm{Ca} \times \mathrm{Mg} \times \mathrm{Zn}), \mathrm{Mg}^{2+}, \mathrm{Al}^{3+}$ and $\mathrm{Zn}^{2+}(\mathrm{Mg} \times \mathrm{Al} \times \mathrm{Zn})$ and $\mathrm{Al}^{3+}, \mathrm{Mn}^{2+}$ and $\mathrm{Zn}^{2+}(\mathrm{Al} \times \mathrm{Mn} \times \mathrm{Zn})$. In the 4-way interactions, the only significant interaction was between $\mathrm{Ca}^{2+}, \mathrm{Mg}^{2+}, \mathrm{Mn}^{2+}$ and $\mathrm{Zn}^{2+}$ whereas the 5-way interactions were also significant.

In the ZB2 culture, the 2-way interaction effects between $\mathrm{Ca}^{2+}$ and $\mathrm{Al}^{3+}(\mathrm{Ca} \times \mathrm{Al}), \mathrm{Mg}^{2+}$ and $\mathrm{Al}^{3+}(\mathrm{Mg} \times \mathrm{Al})$ and $\mathrm{Al}^{3+}$ and $\mathrm{Mn}^{2+}$ $(\mathrm{Al} \times \mathrm{Mn})$ were significant. The AAg of $\mathrm{ZB} 2$ increased from $41-55 \%$ when exposed to $\mathrm{Al}^{3+}$ concentration of $20 \mathrm{mg} / \mathrm{L}$, but decreased from $62-50 \%$ when $\mathrm{Ca}^{2+}$ concentration of $100 \mathrm{mg} / \mathrm{L}$ was added (Fig. 13). In contrast, AAg of ZB2 culture increased from 49-50\% when exposed to $\mathrm{Al}^{3+}$ and $\mathrm{Mg}^{2+}$ concentrations of $20 \mathrm{mg} / \mathrm{L}$ and $40 \mathrm{mg} / \mathrm{L}$, respectively and further increased to $59 \%$ when $\mathrm{Mg}^{2+}$ was excluded from the culture as shown in Table 6 .

For the interaction effect between $\mathrm{Mg}^{2+}$ and $\mathrm{Al}^{3+}$, AAg of ZB1 culture slightly increased from 55-56\% when exposed to $\mathrm{Mg}^{2+}$ and $\mathrm{Al}^{3+}$ concentrations of $40 \mathrm{mg} / \mathrm{L}$ and $20 \mathrm{mg} / \mathrm{L}$, respectively but was in the range of $50-60 \%$ when $\mathrm{Mg}^{2+}$ was excluded. In the ZB2 culture, AAg decreased from $52-50 \%$ when exposed to $\mathrm{Zn}^{2+}$ concentration of $5 \mathrm{mg} / \mathrm{L}$ and further decreased from 56-54\% when $\mathrm{Al}^{3+}$ concentration of $20 \mathrm{mg} / \mathrm{L}$ was added to the culture.

In the 3-way interactions, the two significant interactions were between $\mathrm{Ca}^{2+}, \mathrm{Mg}^{2+}$ and $\mathrm{Mn}^{2+}\left(\mathrm{Ca} \times \mathrm{Mg} \times \mathrm{Mn}^{2+}\right)$ and $\mathrm{Ca}^{2+}, \mathrm{Mg}^{2+}$ and $\mathrm{Zn}^{2+}(\mathrm{Ca} \times \mathrm{Mg} \times \mathrm{Zn})$ (figure not shown).

3.2.5. Interaction effect of cations on SHb for ZL, ZB1 and ZB2 The significant 2-way interaction effect on $\mathrm{ZL} \mathrm{SHb}$ was observed between $\mathrm{Ca}^{2+}$ and $\mathrm{Al}^{3+}(\mathrm{Ca} \times \mathrm{Al}), \mathrm{Mg}^{2+}$ and $\mathrm{Al}^{3+}(\mathrm{Mg} \times \mathrm{Al})$, $\mathrm{Mn}^{2+}$ and $\mathrm{Zn}^{2+}(\mathrm{Mn} \times \mathrm{Zn})$ and $\mathrm{Mg}^{2+}$ and $\mathrm{Mn}^{2+}(\mathrm{Mg} \times \mathrm{Mn})$ as shown in Table 8. 
The SHb of ZL culture decreased from 18-15\% when exposed to $\mathrm{Al}^{3+}$ concentration of $20 \mathrm{mg} / \mathrm{L}$, but increased from $21-24 \%$ when $\mathrm{Ca}^{2+}$ concentration of $100 \mathrm{mg} / \mathrm{L}$ was added to the culture (Fig. 14). Exposure of the ZL culture to $\mathrm{Mn}^{2+}$ concentration of $10 \mathrm{mg} / \mathrm{L}$ caused a decrease of $\mathrm{SHb}$ from $20-14 \%$, but showed an increasing trend from $20-24 \%$ when $\mathrm{Mg}^{2+}$ concentration of $40 \mathrm{mg} / \mathrm{L}$ was added to the culture Fig. 14.

The SHb of ZL culture also decreased from 18-14\% when exposed to $\mathrm{Zn}^{2+}$ concentration of $5 \mathrm{mg} / \mathrm{L}$ and further decreased from $23-21 \%$ when $\mathrm{Zn}^{2+}$ and $\mathrm{Mg}^{2+}$ concentrations of $10 \mathrm{mg} / \mathrm{L}$ and $40 \mathrm{mg} / \mathrm{L}$ was added to the culture. The SHb further decreased from 19-14\% when exposed to $\mathrm{Al}^{3+}$ concentration of $20 \mathrm{mg} / \mathrm{L}$ and further decreased from $62-50 \%$ when $\mathrm{Ca}^{2+}$ concentration of $100 \mathrm{mg} / \mathrm{L}$ was added to the culture. In the 3-way interactions of the ZL culture, the five significant interactions was between $\mathrm{Ca}^{2+}, \mathrm{Mg}^{2+}$ and $\mathrm{Al}^{3+}(\mathrm{Ca} \times \mathrm{Mg} \times \mathrm{Al}), \mathrm{Ca}^{2+}, \mathrm{Al}^{3+}$ and $\mathrm{Mn}^{2+}(\mathrm{Ca} \times \mathrm{Al} \times \mathrm{Mn})$, $\mathrm{Ca}^{2+}, \mathrm{Al}^{3+}$ and $\mathrm{Zn}^{2+}(\mathrm{Ca} \times \mathrm{Al} \times \mathrm{Zn}), \mathrm{Mg}^{2+}, \mathrm{Al}^{3+}$ and $\mathrm{Zn}^{2+}\left(\mathrm{Mg}^{2+}\right.$ $\left.\times \mathrm{Al}^{3+} \times \mathrm{Zn}^{2+}\right), \mathrm{Ca}^{2+}, \mathrm{Mg}^{2+}$ and $\mathrm{Mn}^{2+}(\mathrm{Ca} \times \mathrm{Mg} \times \mathrm{Mn})$, and

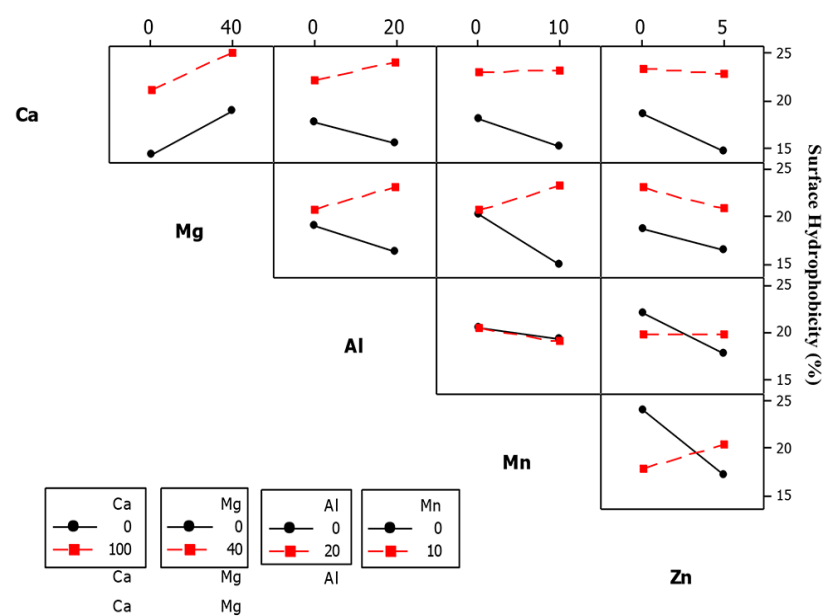

Fig. 14. Interaction plot for ZL SHb.

Table 8. The $P$-values of the Estimated Interaction Effects of Divalent and Trivalent Cations on the SHb\% of ZL, ZB1 and ZB2

\begin{tabular}{|c|c|c|c|c|c|c|}
\hline \multirow{2}{*}{ Factors } & \multicolumn{2}{|c|}{ ZL } & \multicolumn{2}{|c|}{ ZB1 } & \multicolumn{2}{|c|}{ ZB2 } \\
\hline & Estimated effect & SHb\% & Estimated effect & SHb\% & Estimated effect & SHb \% \\
\hline \multicolumn{7}{|c|}{ 2-way interaction } \\
\hline $\mathrm{Ca} \times \mathrm{Al}$ & 2.125 & 0.054 & 2.043 & 0.024 & 5.208 & 0.085 \\
\hline $\mathrm{Mg} \times \mathrm{Al}$ & 2.577 & 0.021 & 1.483 & 0.205 & 3.367 & 0.259 \\
\hline $\mathrm{Al} \times \mathrm{Mn}$ & -0.044 & 0.967 & 0.310 & 0.788 & 9.900 & 0.002 \\
\hline $\mathrm{Al} \times \mathrm{Zn}$ & 2.179 & 0.049 & 2.046 & 0.084 & 2.691 & 0.365 \\
\hline $\mathrm{Ca} \times \mathrm{Mg}$ & -0.353 & 0.742 & 2.724 & 0.024 & 0.275 & 0.926 \\
\hline $\mathrm{Ca} \times \mathrm{Mn}$ & 1.664 & 0.127 & -3.022 & 0.013 & -3.326 & 0.264 \\
\hline $\mathrm{Ca} \times \mathrm{Zn}$ & 1.654 & 0.130 & 2.757 & 0.022 & -2.982 & 0.316 \\
\hline $\mathrm{Mg} \times \mathrm{Mn}$ & 3.971 & 0.001 & -0.976 & 0.401 & 6.219 & 0.041 \\
\hline $\mathrm{Mg} \times \mathrm{Zn}$ & 0.001 & 0.999 & -1.021 & 0.380 & -0.455 & 0.877 \\
\hline $\mathrm{Mn} \times \mathrm{Zn}$ & 4.675 & 0.000 & -0.939 & 0.419 & -3.552 & 0.234 \\
\hline \multicolumn{7}{|c|}{ 3-way interaction } \\
\hline $\mathrm{Ca} \times \mathrm{Mg} \times \mathrm{Al}$ & 2.697 & 0.016 & 1.484 & 0.205 & -3.685 & 0.217 \\
\hline $\mathrm{Ca} \times \mathrm{Al} \times \mathrm{Mn}$ & -2.874 & 0.011 & -0.464 & 0.689 & -1.314 & 0.000 \\
\hline $\mathrm{Ca} \times \mathrm{Al} \times \mathrm{Zn}$ & -2.355 & 0.034 & -4.902 & 0.000 & -1.559 & 0.598 \\
\hline $\mathrm{Mg} \times \mathrm{Al} \times \mathrm{Mn}$ & 0.639 & 0.552 & -2.016 & 0.088 & 6.493 & 0.034 \\
\hline $\mathrm{Mg} \times \mathrm{Al} \times \mathrm{Zn}$ & -1.847 & 0.092 & -0.035 & 0.976 & -0.185 & 0.950 \\
\hline $\mathrm{Al} \times \mathrm{Mn} \times \mathrm{Zn}$ & 1.453 & 0.181 & -2.552 & 0.033 & -2.016 & 0.496 \\
\hline $\mathrm{Ca} \times \mathrm{Mg} \times \mathrm{Mn}$ & 1.191 & 0.271 & 3.118 & 0.011 & 16.488 & 0.000 \\
\hline $\mathrm{Ca} \times \mathrm{Mg} \times \mathrm{Zn}$ & -3.049 & 0.007 & 0.478 & 0.680 & 1.209 & 0.682 \\
\hline $\mathrm{Ca} \times \mathrm{Mn} \times \mathrm{Zn}$ & 1.937 & 0.078 & -1.214 & 0.298 & 4.357 & 0.146 \\
\hline $\mathrm{Mg} \times \mathrm{Mn} \times \mathrm{Zn}$ & -0.780 & 0.181 & -1.758 & 0.135 & -0.729 & 0.806 \\
\hline \multicolumn{7}{|c|}{ 4-way interaction } \\
\hline $\mathrm{Ca} \times \mathrm{Mg} \times \mathrm{Al} \times \mathrm{Mn}$ & -1.216 & 0.261 & -2.196 & 0.065 & -1.877 & 0.526 \\
\hline $\mathrm{Ca} \times \mathrm{Mg} \times \mathrm{Al} \times \mathrm{Zn}$ & 2.078 & 0.059 & -3.921 & 0.002 & 1.320 & 0.655 \\
\hline $\mathrm{Ca} \times \mathrm{Al} \times \mathrm{Mn} \times \mathrm{Zn}$ & 0.942 & 0.382 & -0.304 & 0.006 & 1.903 & 0.520 \\
\hline $\mathrm{Ca} \times \mathrm{Mg} \times \mathrm{Mn} \times \mathrm{Zn}$ & 3.555 & 0.002 & -3.382 & 0.793 & 3.236 & 0.277 \\
\hline $\mathrm{Mg} \times \mathrm{Al} \times \mathrm{Mn} \times \mathrm{Zn}$ & 0.018 & 0.986 & 2.058 & 0.082 & 0.694 & 0.814 \\
\hline \multicolumn{7}{|c|}{ 5-way interaction } \\
\hline $\mathrm{Ca} \times \mathrm{Mg} \times \mathrm{Al} \times \mathrm{Mn} \times \mathrm{Zn}$ & 0.173 & 0.872 & -3.487 & 0.005 & -2.475 & 0.404 \\
\hline
\end{tabular}

Significant Level $=90 \%(0.1)$ 


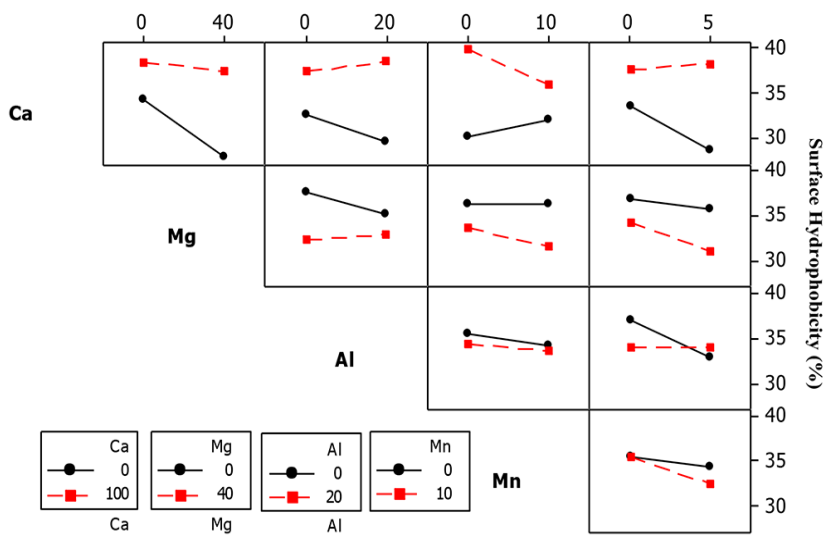

$\mathrm{Zn}$

Fig. 15. Interaction plot for ZB1 SHb.

$\mathrm{Ca}^{2+}, \mathrm{Mg}^{2+}$ and $\mathrm{Zn}^{2+}(\mathrm{Ca} \times \mathrm{Mg} \times \mathrm{Zn})$. In the 4-way interactions, two groups were significant including $\mathrm{Ca}^{2+}, \mathrm{Mg}^{2+}, \mathrm{Al}^{3+}$ and $\mathrm{Zn}^{2+}$ $(\mathrm{Ca} \times \mathrm{Mg} \times \mathrm{Al} \times \mathrm{Zn})$ and $\mathrm{Ca}^{2+}, \mathrm{Mg}^{2+}, \mathrm{Mn}^{2+}$ and $\mathrm{Zn}^{2+}(\mathrm{Ca} \times$ $\mathrm{Mg} \times \mathrm{Mn} \times \mathrm{Zn})$. The 5-way interactions had significant effect on $\mathrm{SHb}$ (figure not shown).

In the ZB1 culture, the $\mathrm{SHb}$ for the 2-way interactions between $\mathrm{Ca}^{2+}$ and $\mathrm{Mg}^{2+}(\mathrm{Ca} \times \mathrm{Mg}), \mathrm{Ca}^{2+}$ and $\mathrm{Al}^{3+}(\mathrm{Ca} \times \mathrm{Al}), \mathrm{Ca}^{2+}$ and $\mathrm{Mn}^{2+}(\mathrm{Ca} \times \mathrm{Mn}), \mathrm{Ca}^{2+}$ and $\mathrm{Zn}^{2+}(\mathrm{Ca} \times \mathrm{Zn})$ and $\mathrm{Mn}^{2+}$ and $\mathrm{Zn}^{2+}$ $(\mathrm{Mn} \times \mathrm{Zn})$ were significant. The interaction effect of the cations on the $\mathrm{SHb}$ of $\mathrm{ZB1}$ is shown in Fig. 15. The SHb decreased from $35-18 \%$ when ZB1 culture was exposed to $\mathrm{Mg}^{2+}$ concentration of $40 \mathrm{mg} / \mathrm{L}$ and further decreased from $39-37 \%$ when $\mathrm{Ca}^{2+}$ concentration of $100 \mathrm{mg} / \mathrm{L}$ was added. This showed that only $\mathrm{Ca}^{2+}$ effect influenced the $\mathrm{SHb}$ since addition of $\mathrm{Mg}^{2+}$ decreased the $\mathrm{SHb}$. A similar decrease of SHb from 33-28\% was observed when the ZB1 culture was exposed to $\mathrm{Al}^{3+}$ concentration of $20 \mathrm{mg} / \mathrm{L}$, but increased from $37-39 \%$ when $\mathrm{Ca}^{2+}$ concentration of $100 \mathrm{mg} / \mathrm{L}$ was added (Fig. 15).

In contrast, the $\mathrm{SHb}$ of ZB1 culture increased from 28-32\% when exposed to $\mathrm{Mn}^{2+}$ concentration of $10 \mathrm{mg} / \mathrm{L}$, but decreased from $40-35 \%$ when $\mathrm{Ca}^{2+}$ concentration of $100 \mathrm{mg} / \mathrm{L}$ was added to the culture. The SHb slightly decreased from $36-35 \%$ when exposed to $\mathrm{Zn}^{2+}$ concentration of $5 \mathrm{mg} / \mathrm{L}$ and further decreased from $36-32 \%$ when $\mathrm{Ca}^{2+}$ concentration of $100 \mathrm{mg} / \mathrm{L}$ was added to the culture (Fig. 16). However, SHb slightly increased from $37-38 \%$ when exposed to $\mathrm{Zn}^{2+}$ and $\mathrm{Mn}^{2+}$ concentrations of $5 \mathrm{mg} / \mathrm{L}$ and $10 \mathrm{mg} / \mathrm{L}$, respectively. In the 2-way interactions, the three significant interaction groups for $\mathrm{SHb}$ were $\mathrm{Ca}^{2+}$ and $\mathrm{Al}^{3+}(\mathrm{Ca}$ $\times \mathrm{Al}), \mathrm{Al}^{3+}$ and $\mathrm{Mn}^{2+}(\mathrm{Al} \times \mathrm{Mn})$ and $\mathrm{Mg}^{2+}$ and $\mathrm{Mn}^{2+}(\mathrm{Mg} \times$ $\mathrm{Mn}$ ) (Table 8). The $\mathrm{SHb}$ decreased from $47-42 \%$ when exposed to $\mathrm{Al}^{3+}$ concentration of $20 \mathrm{mg} / \mathrm{L}$, but increased from $47-55 \%$ when $\mathrm{Ca}^{2+}$ concentration of $100 \mathrm{mg} / \mathrm{L}$ was added to the culture.

In the ZB2 culture, the $\mathrm{SHb}$ decreased from $50-45 \%$ when exposed to $\mathrm{Mn}^{2+}$ concentration of $10 \mathrm{mg} / \mathrm{L}$, but increased from $40-56 \%$ when $\mathrm{Al}^{3+}$ concentration of $20 \mathrm{mg} / \mathrm{L}$ was added to the culture for the three way interaction (Fig. 16). SHb also decreased from $52-50 \%$ when exposed to $\mathrm{Mn}^{2+}$ concentration of $10 \mathrm{mg} / \mathrm{L}$, but increased from $40-53 \%$ when $\mathrm{Mg}^{2+}$ concentration of $40 \mathrm{mg} / \mathrm{L}$ was added to the culture (Fig. 16).

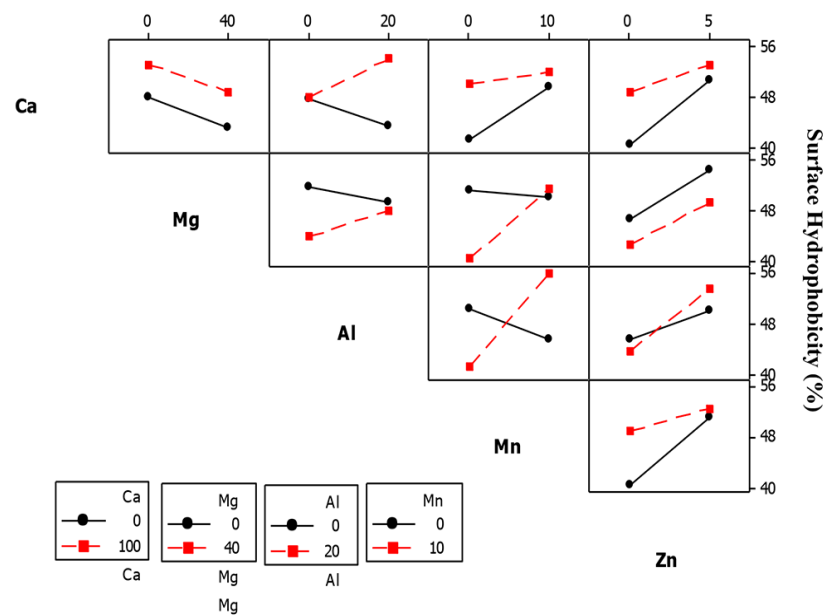

Fig. 16. Interaction plot for ZB2 SHb.

The five significant interaction groups in the 3-way interaction effects on $\mathrm{SHb}$ of $\mathrm{ZB} 2$ were between $\mathrm{Ca}^{2+}, \mathrm{Mg}^{2+}$ and $\mathrm{Al}^{3+}(\mathrm{Ca}$ $\times \mathrm{Mg} \times \mathrm{Al}), \mathrm{Mg}^{2+}, \mathrm{Al}^{3+}$ and $\mathrm{Mn}^{2+}(\mathrm{Mg} \times \mathrm{Al} \times \mathrm{Mn}), \mathrm{Ca}^{2+}, \mathrm{Mg}^{2+}$ and $\mathrm{Mn}^{2+}(\mathrm{Ca} \times \mathrm{Mg} \times \mathrm{Mn}), \mathrm{Mg}^{2+}, \mathrm{Al}^{3+}$ and $\mathrm{Mn}^{2+}(\mathrm{Mg} \times \mathrm{Al}$ $\times \mathrm{Mn})$ and $\mathrm{Al}^{3+}, \mathrm{Mn}^{2+}$ and $\mathrm{Zn}^{2+}(\mathrm{Al} \times \mathrm{Mn} \times \mathrm{Zn})($ Table 8$)$. In the 4-way interactions, the two significant groups were calcium, magnesium, aluminium, and manganese $\left(\mathrm{Ca}^{2+} \times \mathrm{Mg}^{2+} \times \mathrm{Al}^{3+}\right.$ $\left.\times \mathrm{Mn}^{2+}\right)$ and calcium, magnesium, manganese and zinc $\left(\mathrm{Ca}^{2+}\right.$ $\left.\times \mathrm{Mg}^{2+} \times \mathrm{Mn}^{2+} \times \mathrm{Zn}^{2+}\right)$. The 5-way interactions also had significant effect on ZB2 SHb.

High interactions amongst the cations did not influence the $\mathrm{AAg}$ and $\mathrm{SHb}$ of microbial organisms. From the experiment and analysis, most of the cations had effects that could stimulate the microbial AAg and SHb. Literally, $\mathrm{Ca}^{2+}$ and $\mathrm{Mg}^{2+}$ were the most influential cation binder and played a vital role in microbial aggregation [23]. In biological treatment, $\mathrm{Al}^{3+}$ is the second most influential ion binder and it is known to enhance AAg of microorganisms [29, 58].

The significant effect of the combination of cations on AAg and $\mathrm{SHb}$ for each species of bacteria tested differed. Some of the cations such as $\mathrm{Ca}^{2+}$ had similar effects in all three bacteria. The presence of single or a mixture of cations caused different effects towards each of the species of bacteria. The result obained also showed that the presence of cations influenced the bacterial diversity for AAg and SHb. The relationship between AAg and SHb for the three bacteria was correlative. However the selection of the most performing cations could not rely on the significant effects obtained from ANOVA.

Rahman et al. [2] reported that heterogeneity of bacteria play a vital role in $\mathrm{SHb}$. Heterogeneity in $\mathrm{SHb}$ of different bacterial strains was also reported by Del Re et al. [40]. According to Perez et al. [59], heterogeneity in SHb was due to the involvement of several factors interfering with adhesion of cells to hydrocarbons. Thus cations could be the factors that influence the heterogeneity of bacteria. Thus, different effects were observed for the various bacteria strains or species. There was good correlation between $\mathrm{AAg}$ and $\mathrm{SHb}$ in the three bacteria. This indicates that $\mathrm{SHb}$ and AAg results are similar and SHb could be one of the determinants of AAg. Similar to AAg, the statistical result on SHb to some extent 
provides an explanation with respect to the presence of cations towards $\mathrm{SHb}$ of cells structure and granule formation $[18,60]$.

\section{Conclusions}

The investigated input variables i.e. divalent and trivalent cations imposed significant linear effect on the selected bacterial aggregation and $\mathrm{SHb}$. The ANOVA showed an overall result. Thus, $\mathrm{Ca}^{2+}$ gave the most significant effect on $\mathrm{AAg}$ and $\mathrm{SHb}$ of the selected bacteria experimented. Overall, the factorial design was purposely used in this study to test the effects of cations on the selected bacteria through the estimation of the equivalent $\mathrm{AAg} \%$ and $\mathrm{SHb} \%$. In the presence of the cations especially $\mathrm{Ca}^{2+}, \mathrm{ZB} 2$ had an aggregation up to $62 \%$ which was the highest AAg amongst all of them. This was followed by ZB1 and ZL at $58 \%$ and $34 \%$, respectively. The AAg of each bacteria correlated to the SHb.

\section{Acknowledgements}

The authors wish to thank the Ministry of Science, Technology and Innovation (MOSTI), Ministry of Higher Education (MOHE), and Universiti Teknologi Malaysia for financial support for this research (Grant No. 01H08 and 4L119).

\section{References}

1. Chen F. Bacterial auto-aggregation and co-aggregation in activated sludge [thesis]. Clemson University, USA; 2007.

2. Rahman MM, Kim WS, Kumura H, Shimazaki KI. Autoaggregation and surface hydrophobicity of Bifidobacteria. World J. Microb. Biotech. 2008;24:1593-1598.

3. Kos B, Suskovic J, Vukovic S, Simpraga M, Frece J, Matosic S. Adhesion and aggregation ability of probiotic strain lactobacillus acidophilus M92. J. Appl. Microbiol. 2003;94:981-987.

4. Nomura T, Narahara H, Tokumoto H, Konishi Y. The role of microbial surface properties and extracellular polymer in lactococcus lactis aggregation. Adv. Powder Technol. 2009;20: 537-541.

5. Liu Y, Yang SF, Tay JH, Liu QS, Qin L, Li Y. Cell hydrophobicity is a triggering force of biogranulation. Enzym. Microb. Technol. 2004;34:371-379.

6. Aslim B, Onal D, Beyatli Y. Factors influencing autoaggregation and aggregation of lactobacillus delbrueckii subsp. bulgaricus isolated from handmade yogurt. J. Food Protect. 2007;70:223-227.

7. Adav SS, Lee DJ. Intrageneric and intergeneric co-aggregation with acinetobacter calcoaceticus I6. J. Taiwan Inst. Chem. Eng. 2009;40:344-347.

8. Sheng GP, Yu HQ, Li XY. Extracellular polymeric substances (EPS) of microbial aggregates in biological wastewater treatment systems: A review. Biotechnol. Adv. 2010;28:882-894.

9. Guo F, Zhang SH, Yu X, Wei B. Variations of both bacterial community and extracellular polymers: The inducements of increase of cell hydrophobicity from biofloc to aerobic granule sludge. Biores. Technol. 2011;102:6421-6428.
10. Muda K, Aris A, Salim MR, et al. Aggregation and surface hydrophobicity of selected microorganism due to the effect of substrate, $\mathrm{pH}$ and temperature. Int. Biodeter. Biodegrad. 2014;93:202-209.

11. Liu Y, Tay JH. The essential role of hydrodynamic shear force in the formation of biofilm and granular sludge. Water Res. 2002;36:1653-1665.

12. Tay JH, Tay STL, Liu Y, Show KY, Ivanov V. Biogranulation technologies for wastewater treatment: Microbial granules. 1st ed. Elsevier Science; 2006.

13. Di Iaconi C, Ramadori R, Lopez A, Passino R. Aerobic granular sludge systems: The new generation of wastewater treatment technologies. Ind. Eng. Chem. Res. 2007;46:6661-6665.

14. Adav SS, Lee DJ, Show KY, Tay JH. Aerobic granular sludge: Recent advances. Biotechnol. Adv. 2008a;26:411-423.

15. Liu XW, Sheng GP, Yu HQ. Physicochemical characteristics of microbial granules. Biotechnol. Adv. 2009;27:1061-1070.

16. Sutherland IW. Exopolysaccharides in biofilms, flocs and related structures. Water Sci. Technol. 2001;43:77-86.

17. Chen H, Zhou S, Li T. Impact of extracellular polymeric substances on the settlement ability of aerobic granular sludge. Environ. Technol. 2010;31:1601-1612.

18. Wang ZW, Liu Y, Tay JH. Distribution of EPS and cell surface hydrophobicity in aerobic granules. Appl. Microbiol. Biotechnol. 2005:69:469-473.

19. Wang Z, Liu L, Yao J, Cai W. Effects of extracellular polymeric substances on aerobic granulation in sequencing batch reactors. Chemosphere 2006;63:1728-1735.

20. Zhang L, Feng X, Zhu N, Chen J. Role of extracellular protein in the formation and stability of aerobic granules. Enzym. Microb. Technol. 2007;41:551-557.

21. Seviour T, Zhiguo Y, Loosdrecht MCMV, Lin Y. Aerobic sludge granulation: A tale of two polysaccharides? Water Res. 2012;46:4803-4813.

22. Wang S, Shi W, Yu S, Yi X, Yang X. Formation of aerobic granules by $\mathrm{Mg}^{2+}$ and $\mathrm{Al}^{3+}$ augmentation in sequencing batch airlift reactor at low temperature. Bioproc. Biosys. Eng. 2012;35: 1049-1055.

23. Liu L, Gao DW, Zhang M, Fu Y. Comparison of $\mathrm{Ca}^{2+}$ and $\mathrm{Mg}^{2+}$ enhancing aerobic granulation in SBR. J. Hazard. Mater. 2010;181:382-387.

24. Zheng X, Chen W, Zhu N, Wu D, Wang Y. Effect of Zn(Ii) on the characteristics of aerobic granules. J. Food Agric. Environ. 2011;9:497-500.

25. Mahoney EM, Varangu LK, Cairns WL, Kosaric N, Murray RGE. The effect of calcium on microbial aggregation During UASB reactor start-up. Water Sci. Technol. 1987;19:249-260.

26. Sondhi A, Guha S, Harendranath CS, Singh A. Effect of aluminum $\left(\mathrm{Al}^{3+}\right)$ on granulation in upflow anaerobic sludge blanket reactor treating low-strength synthetic wastewater. Water Environ. Res. 2010;82:715-724.

27. El-Mamouni R, Leduc R, Guiot SR. Influence of synthetic and natural polymers on the anaerobic granulation process. Water Sci. Technol. 1998;38:341-347.

28. Uyanik S, Sallis PJ, Anderson GK. The effect of polymer addition on granulation in an anaerobic baffled reactor (ABR). Part I: Process performance. Water Res. 2002;36:933-943. 
29. Liu Z, Liu Y, Zhang A, Zhang C, Wang X. Study on the process of aerobic granule sludge rapid formation by using the poly aluminium chloride (PAC). Chem. Eng. J. 2014;250:319-325.

30. Jiang HL, Tay JH, Liu Y, Tay ST. $\mathrm{Ca}^{2+}$ augmentation for enhancement of aerobically grown microbial granules in sludge blanket reactors. Biotechnol. Lett. 2003;25:95-99.

31. Pevere A, Guibaud G, Van Hullebusch ED, Boughzala W, Lens PNL. Effect of $\mathrm{Na}^{+}$and $\mathrm{Ca}^{2+}$ on the aggregation properties of sieved anaerobic granular sludge. Colloid. Surface. A. 2007;306:142-149.

32. De Kreuk MK, Van Loosdrecht MC. Selection of slow growing organisms as a means for improving aerobic granular sludge stability. Water Sci. Technol. 2004;49:9-17.

33. Di Iaconi C, Ramadori R, Lopez A, Passino R. Aerobic granular sludge systems: The new generation of wastewater treatment technologies. Ind. Eng. Chem. Res. 2007;46:6661-6665.

34. Liu Y, Tay JH. State of the art of biogranulation technology for wastewater treatment. Biotechnol. Adv. 2004;22:533-563.

35. Muda K, Aris A, Salim MR, et al. Development of granular sludge for textile wastewater treatment. Water Res. 2010;44: 4341-4350.

36. Zheng X, Chen W, Zhu N, Wu D, Wang Y. Effect of Zn(Ii) on the characteristics of aerobic granules. J. Food Agric. Environ. 2011;9:497-500.

37. Kerchove AJ, Elimelech M. Calcium and magnesium cations enhance the adhesion of motile and nonmotile pseudomonas aeruginosa on alginate films. Langmuir 2008;24:3392-3399.

38. Lamprecht C. UASB granulation enhancement by microbial inoculum selection and process induction. [thesis]. Stellenbosch: Univ. of Stellenbosch; 2009.

39. Malik A, Sakamoto M, Hanazaki S, et al. Coaggregation among nonflocculating bacteria isolated from activated sludge. Appl. Environ. Microbiol. 2003;69:6056-6063.

40. Del Re B, Sgorbati B, Miglioli M, Palenzona D. Adhesion, autoaggregation and hydrophobicity of 13 strains of Bifidobacterium longum. Lett. Appl. Microbiol. 2000;31:438-442.

41. Nishiyama S, Murakami Y, Nagata H, Shizukuishi S, Kawagishi I, Yoshimura F. Involvement of minor components associated with the fima fimbriae of porphyromonas gingivalis in adhesive functions. Microbiology 2007;153:1916-1925.

42. Lim CK, Bay HH, Aris A, Abdul Majid Z, Ibrahim Z. Biosorption and biodegradation of acid orange 7 by enterococcus faecalis strain ZL: Optimization by response surface methodological approach. Environ. Sci. Pollut. Res. Int. 2013;20:5056-5066.

43. Kee TC, Bay HH, Lim CK, Muda K, Ibrahim Z. Development of bio-granules using selected mixed culture of decolorizing bacteria for the treatment of textile wastewater. Desalin. Water Treat. 2014;54:1-8.

44. Bay HH, Lim CK, Kee TC, et al. Decolourisation of acid orange 7 recalcitrant auto-oxidation coloured by-products using an acclimatised mixed bacterial culture. Environ. Sci. Pollut. Res. Int. 2014;21;3891-3906.

45. Tezuka Y. Cation-dependent flocculation in a flavobacterium species predominant in activated sludge. Appl. Microbiol. 1969;17:222-226.

46. Mckinney RE, Horwood MP. Fundamental approach to the activated sludge process: I. Floc-producing bacteria. Sew. Ind. Wast. 1952;24:117-123.

47. Sobeck DC, Higgins MJ. Examination of three theories for mechanisms of cation-induced bioflocculation. Water Res. 2002;36: 527-538.

48. Li XM, Liu QQ, Yang Q, et al. Enhanced aerobic sludge granulation in sequencing batch reactor by $\mathrm{Mg}^{2+}$ augmentation. Biores. Technol. 2009;100:64-67.

49. Nguyen TP, Hilal N, Hankins NP, Novak JT. The relationship between cation ions and polysaccharide on the floc formation of synthetic and activated sludge. Desalination 2008;227:94-102.

50. Mara D, Horan NJ. Handbook of water and wastewater microbiology. 1st ed. Elsevier Science; 2003.

51. Huang L, Yang T, Wang W, Zhang B, Sun Y. Effect of $\mathrm{Mn}^{2+}$ augmentation on reinforcing aerobic sludge granulation in a sequencing batch reactor. Environ. Biotech. 2012;93:2615-2623.

52. Lin CY, Chen CC. Toxicity-resistance of sludge biogranules to heavy metals. Biotechnol. Lett. 1997;19:557-560.

53. Higgins MJ and Novak JT. The effects of cations on the settling and dewatering of activated sludge: Laboratory experience. Water Environ. Res. 1997;69:215-224.

54. Foster PL. Stress-induced mutagenesis in bacteria. Crit. Rev. Biochem. Mol. Biol. 2007;42:373-397.

55. Li H, Wen Y, Cao A, Huang J, Zhou Q, Somasundaran P. The influence of additives $\left(\mathrm{Ca}^{2+}, \mathrm{Al}^{3+}\right.$, and $\left.\mathrm{Fe}^{3+}\right)$ on the interaction energy and loosely bound extracellular polymeric substances (EPS) of Activated sludge and their flocculation mechanisms. Biores. Technol. 2012;114:188-194.

56. Adav SS, Lee DJ, Tay JH. Extracellular polymeric substances and structural stability of aerobic granule. Water Res. 2008b;42: 1644-1650.

57. Park C, Muller CD, Abu-Orf MM, Novak JT. The effect of wastewater cations on activated sludge characteristics: Effects of aluminium and iron in floc. Water Environ. Res. 2006;78:31-40.

58. Yu HQ, Fang HHP, Tay JH. Enhanced sludge granulation in upflow anaerobic sludge blanket (UASB) reactors by aluminum chloride. Chemosphere 2001;44:31-36.

59. Perez M, Romero LI, Sales D. Comparative performance of high rate anaerobic thermophilic technologies treating industrial wastewater. Water Res. 1998;32:559-564.

60. Zita A, Hermansson M. Effects of bacterial cell surface structures and hydrophobicity on attachment to activated sludge flocs. Appl. Environ. Microbiol. 1997;63:1168-1170. 